\title{
ASSESSING THE HARMLESSNESS OF FEDERAL CONSTITUTIONAL ERROR- A PROCESS IN NEED OF A RATIONALE
}

\author{
Martha A. Field $\dagger$
}

In Chapman $v$. California, ${ }^{1}$ the Supreme Court announced some fundamental principles shaping the law of harmless constitutional error in criminal proceedings. First, the Court ended an aged assumption that constitutional error would always require reversal if the Supreme Court reviewed the case. ${ }^{2}$ Next, the Court ruled that in cases containing federal constitutional error the standard of harmlessness is a federal question, not a matter of state law. ${ }^{3}$ Finally, the Court placed the burden on "the beneficiary of a constitutional error to prove beyond a reasonable doubt that the error complained of did not contribute to the verdict obtained."4

Although Supreme Court cases have followed these principles rather consistently since Chapman, ${ }^{5}$ the problem of the con-

$\dagger$ Associate Professor of Law, University of Pennsylvania. A.B. 1965, Radcliffe College; J.D. 1968, University of Chicago Law School. Member, District of Columbia Bar.

Support for this Article was provided by the Henry Temin Fund. I wish gratefully to acknowledge the assistance of Robert E. Anderson, J.D. 1976, University of Pennsylvania Law School.

1386 U.S. 18 (1967).

${ }^{2}$ See id. at 42-45 (Stewart, J., concurring). The only case in which the Court had found constitutional error harmless was Motes v. United States, 178 U.S. 458 (1900) (involving testimony, violative of the sixth amendment confrontation clause, introduced against a defendant who admitted his guilt at trial). The case is discussed in text accompanying notes $82-86$ infra.

State courts had not shared the Supreme Court's reluctance to hold that federal constitutional errors were harmless. See note 65 infra \& accompanying text.

${ }^{3}$ Justice Harlan dissented vigorously on this point. 386 U.S. at 45-54. He believed that harmless constitutional error rules, like other state court procedural rules, should be overturned only if they violate the due process clause of the fourteenth amendment by being fundamentally unfair. Apparently he would have considered the approaches to harmless error discussed in this Article legitimate alternatives among which the states might freely choose.

Justice Harlan dissented alone, and his view has not reappeared.

${ }^{4}$ Id. at 24 .

5 The beyond-a-reasonable-doubt formulation has been retained, at least in form, although one might question its application in particular factual settings. See, e.g., Schneble v. Florida, 405 U.S. 427, 431-32 (1972), discussed in text accompanying notes 94-101 infra; Harrington v. California, 395 U.S. 250, 254 (1969), discussed in notes 76, 87 
tent of the federal standard has not been explicitly addressed. Granted the necessity of showing harmlessness beyond a reasonable doubt, the question remains how to make the showing of harmlessness. At least three possibilites for demonstrating harmlessness appear in Supreme Court opinions:

1. The first approach focuses upon the erroneously admitted evidence (or other constitutional error) ${ }^{6}$ to ask whether it might have contributed to a guilty verdict.

2. The second approach asks whether, once erroneously admitted evidence is excluded, there remains overwhelming evidence to support the jury's verdict.

3. The third approach asks whether the tainted evidence is merely cumulative-that is, merely duplicative of some remaining admissible evidence.

Supreme Court opinions often do not distinguish between these variant approaches, although the approach selected can change the disposition of many cases. At times the Court appears to have endorsed the second and third approaches to harmless error, although it sometimes seems to favor the first approach standing alone. I believe that harmlessness should be found only when either the first test or a carefully circumscribed version of the third is satisfied. At the outset, this Article will define and discuss the first two approaches to harmless error and the Supreme Court cases on the subject. It will then develop and analyze the third approach. ${ }^{7}$

I. Polar Positions on the Definition of Harmlessness-The First and Second Approaches

The first two positions defining harmless error can be seen as opposite extremes. The first approach requires examining the erroneously admitted evidence, without regard to the weight of other evidence, to determine whether the error might have swayed the factfinder and contributed to the verdict. The second

\& text accompanying notes $69-75$ infra; In re Cline, 255 Cal. App. 2d 115, 123-24, 63 Cal. Rptr. 233, 239 (1967), cert. denied, 392 U.S. 938 (1968), discussed in note 101 infra.

${ }^{6}$ Through most of this Article, reference will be made to erroneously admitted evidence in discussing errors which may be harmless. The harmless error discussion, however, is relevant as well to constitutional errors that occur at trial other than the erroneous introduction of unconstitutional evidence.

7 Although this Article will discuss harmless constitutional error in criminal trials, much of the general analysis, including the classification of types of error and the discussion of the difficulties involved in the various tests for harmlessness, is applicable by analogy to a broader range of harmless error problems. 
position does not look to the tainted evidence, but to the untainted evidence, and asks whether it alone compels a verdict of guilty. An example will illustrate the difference between the two approaches: in a case in which the constitutional error concerned evidence likely to be influential with a jury-such as an erroneously admitted confession-but in which there was also other overwhelming evidence of the defendant's guilt, the error could not be deemed harmless under the first approach but would be harmless under the second.

In this situation, where the error appears harmful even out of context, the difference between the two approaches is evident: the first approach looks only to the improperly admitted evidence, whereas the second looks only to the properly admitted evidence. In some cases, however, the line between the two is less obvious. The difficulty arises because it is not always possible to determine, by viewing an error in isolation, whether the error could have affected the factfinder. The impact of illegally admitted evidence in a particular case is sometimes apparent only after examining its interaction with properly admitted evidence. Admission of an exculpatory statement obtained in violation of the fifth amendment might not appear prejudicial by itself. But an examination of other evidence in the case might reveal inconsistencies damaging to the defendant-for example, if the statement claimed an alibi that the alibi witness denied at trial. The first approach may, then, require assessing an error in context. ${ }^{8}$

${ }^{8}$ The first approach, assessing harmfulness by looking only to the erroneousiy admitted evidence, varies considerably, then, according to how one defines "the erroneously admitted evidence." In the example in text, "the erroneously admitted evidence" could be described as "evidence admitted in violation of the fifth amendment"; or as "exculpatory statements admitted in violation of the fifth amendment"; or as "exculpatory statements admitted in violation of the fifth amendment that are refuted at trial," and so on. Because the various possible forms of the first approach can lead to different results, it is important as well to establish a principle of selection between them. In the above example, in which an exculpatory statement appeared harmless in itself but was in fact damaging in the context of the case, it seems obvious that the conviction should be overturned because the error actually was of significance. This would seem to suggest that in order to determine harmlessness the rule defining "erroneously admitted evidence" should look to the operation of the erroneously admitted evidence in its particular context rather than to the evidence in isolation. In cases in which a determination of harmfulness can be made at a more generalized level, however, the latter approach will result in an economy of effort. If one is willing to adopt a rule, for example, that the absence of counsel at trial or that the admission of an unconstitutionally obtained confession cannot be deemed harmless, it would be unnecessary to examine the impact of the error in the particular case. Or if one declines to adopt a generic rule with respect to confessions but adjudges a particular confession, viewed apart from the rest of the evidence, as harmful, it will also be harmful, for 
Though not always wholly irrelevant even under the first approach, the properly admitted evidence is relevant there in a very different way than it is under the second, or overwhelming evidence, test. For when the first approach requires examination of the properly admitted evidence, the concern is solely to trace the impact of the erroneously admitted evidence. The untainted evidence is not weighed in its own right, nor is it examined to see if it is cumulative with the tainted evidence; it is considered only to uncover the potentially damaging ramifications of the error. It is that fact that distinguishes "the first approach" in my analysis from "the second approach," where the crucial inquiry is whether the untainted evidence, considered independently of the tainted evidence, would in any event compel a verdict of guilty. Only the weight of the admissible evidence is relevant to that inquiry; the erroneously admitted evidence is irrelevant.

Whichever approach one follows, the beyond-a-reasonabledoubt standard can apply. Looking at the error itself, one can require certainty beyond a reasonable doubt that it would not influence a jury; focusing on the other evidence, one can require certainty beyond a reasonable doubt that it compels a guilty verdict. ${ }^{9}$ Given Chapman v. California, ${ }^{10}$ the beyond-a-reason-

purposes of the first approach, when its interaction with the rest of the evidence is traced. Only when an error seems harmless apart from its context is it necessary, under this approach, to engage in the more extended inquiry whether other evidence makes it harmful. Not only may it be time-consuming to resolve that problem; its resolution will provide less guidance for future cases.

Economy of effort might suggest that a court always should inquire first whether an error generically is harmful and then proceed to the more particularized inquiries only if that question is answered in the negative. A court sometimes, however, might wish to avoid deciding whether errors under a particular constitutional provision are invariably prejudicial. In Fahy v. Connecticut, 375 U.S. 85 (1963), for example, the court deferred the question whether an illegal search and seizure, or indeed any constitutional error, could ever be harmless. Instead it chose to render a decision with less precedential impact by focusing on the facts of the case. See id. at 86.

${ }^{9}$ In order to comply with constitutional demands, an "other evidence" test must, of course, look for overwhelming evidence-such evidence that the jury would necessarily find the defendant guilty. Sufficient evidence to convict, once the tainted evidence is removed, is inadequate to support a finding of harmless error, because a jury may acquit though the evidence is sufficient to refer the case to it. See Fahy v. Connecticut, 375 U.S. 85, 86 (1963). At common law, however, appellate courts would not reverse criminal convictions because of trial error if they believed the jury had reached the correct result on the basis of sufficient evidence. That rule was altered in 1835 by the Court of Exchequer, in an opinion later read to have adopted a position at the opposite extreme: a rule of automatic reversal fortany error, however technical or trivial. Crease v. Barrett, 1 C.M. \& R. 919, 149 Eng. Rep. 1353 (Ex. 1835). This rule was eventually modified both in England and the United States. See generally R. TRAYNOR, THE RIDDLE of Harmless Error 1-26 (1970); $1 \mathrm{~J}$. Wigmore, Evidence \& 21, at 364-68 (3d ed. 1940).

${ }^{10} 386$ U.S. 18 (1967). 
able-doubt standard should be applied whichever approach is selected. But it is important as well to select between the two approaches, or to decide that yet another is mandated, because the different standards can lead to conflicting dispositions of the same case. In the case described above, involving both an improper confession and other overwhelming evidence of guilt, the conviction would be reversible under the first approach but not the second. A situation requiring reversal under the overwhelming evidence test but not under the first approach also seems logically possible: examining a constitutional error might convince one that it could not have influenced the verdict, ${ }^{11}$ but the other evidence in the case, though sufficient to sustain the verdict, might be short of overwhelming. Although application of the second approach alone would dictate reversal in such a case, it is unlikely that a court would reverse when the error itself is so unimportant that it could not have influenced the result. If this is true, the second approach supplements the first rather than presenting an alternative to it. The inquiry, then, is whether the harmless error doctrine should apply to sustain a conviction only when the error itself appears harmless ${ }^{12}$ (as the first approach allows) or whether overwhelming untainted evidence as well can support a finding of harmlessness.

\section{The Special Problem of Generically Harmless Errors}

Whether or not the overwhelming evidence test is proper, the first approach allows a finding of harmlessness when one is certain that an error, whether viewed in isolation or in context, could not have influenced the result. There is, however, a group of constitutional errors that should provide an exception to this general rule. The violation of some constitutional rules may be necessarily harmless: ${ }^{13}$ some rules generally do not have any significant impact on the outcome of a case. While it is arguable what rules would fall within this description, two constitutionally based rules that might be deemed to qualify are the rule pro-

${ }^{11}$ For example, the error might concern an exculpatory statement given by a defendant who had not been given his Miranda warnings. The statement, though erroneously admitted, might be deemed not possibly to have contributed to the finding of guilt.

${ }_{12}$ Note, however, the exception for harmlessness of the generic variety. See text accompanying notes 13-19 infra.

${ }^{13} \mathrm{Cf}$. notes 54-60 infra \& accompanying text, which concern rules whose violation is necessarily harmful and that accordingly lead to automatic reversal. 
hibiting discrimination in jury selection and the rule prohibiting comment on a defendant's failure to testify. In the first example, the argument would be that discriminatory elimination of one group does not influence the result of a trial, absent a showing of bias on the part of those who served. ${ }^{14}$ In the latter example, one would argue that commenting on the defendant's failure to testify simply tells jury members what they have in any case observed. ${ }^{15}$

As a result of a finding of "generic harmlessness," one might be tempted to conclude that the test of harmless-beyond-areasonable-doubt is satisfied and that no reversal for error is required. If that argument were accepted with regard to either example above, however, the result would be effectively to overturn the constitutional rule; ${ }^{16}$ if violation of a rule is generically harmless and cannot lead to reversal, then unless some other means of enforcing the rule is provided, it will be reduced to an empty exhortation. ${ }^{17}$ That one could reach a conclusion of harmlessness does not necessarily argue for repeal of the rule, for rules may serve purposes apart from their effect on the outcome of a particular trial. In the case of discrimination in jury selection, the purpose, at least in part, is to prevent the offense to the dignity of excluded groups of citizens that would result from their elimination. ${ }^{18}$ The rule prohibiting comment on failure to testify may well respresent a judgment that although the comment is likely to have minimal impact on the outcome, the absence of affirmative justification for the comment warrants its prohibition.

If these are the purposes behind the suggested rules, it is obviously nonsensical to apply a harmless error test to them. Indeed, the examples suggest that the harmless error doctrine

${ }^{14}$ But cf. Peters v. Kiff, 407 U.S. 493 (1972).

${ }^{15}$ Cf. Chapman v. California, 386 U.S. 18, 55 (1967) (Harlan, J., dissenting).

${ }^{16}$ Indeed the suggested rationale for holding Griffin violations harmless was urged in Griffin as an argument against adopting the rule in the first instance. Griffin v. California, 380 U.S. 609, 614 (1965); id. at 621-22 (Stewart, J., dissenting).

17 The fact that the plaintiff has not been harmed also might preclude a civil rights action against state officials who violated the rule. In the jury selection example, however, another remedy does exist, though quaere whether it would be sufficiently effective as the sole remedy: excluded groups of citizens may bring a class action charging discriminatory exclusion and, if successful, they may obtain an injunction against continuation of the practice. Carter v. Jury Comm'n, 396 U.S. 320 (1970); Turner v. Fouche, 396 U.S. 346 (1970).

${ }^{18}$ See Peters v. Kiff, 407 U.S. 493 (1972); Turner v. Fouche, 396 U.S. 346 (1970); Carter v. Jury Comm'n, 396 U.S. 320 (1970); Strauder v. West Virginia, 100 U.S. 303, 308 (1880). 
should be deemed inapplicable to generically harmless constitutional rules. Instead, the seemingly paradoxical approach should be adopted that violations of such rules result in automatic reversal, for another result would effectively overturn the constitutional rules. ${ }^{19}$

\section{iII. The Case Law Concerning the Two Approaches}

The case law is not wholly coherent concerning the propriety of finding harmlessness in cases in which there are possibly damaging constitutional errors but also other overwhelming evidence of guilt. On the whole, however, the cases support the propriety of an overwhelming evidence test.

\section{A. Milton v. Wainwright and the Existence of an Overwhelming Evidence Test}

The case most clearly adopting the position that the "overwhelming evidence" test is a proper means to ascertain harmlessness is Milton $v$. Wainwright.$^{20}$ A police officer, Langford, had testified at Milton's trial concerning statements Milton had made to him relating the details of the crime. The statements were made to Officer Langford after Milton had been indicted and had obtained counsel and while Langford, posing as a fellow

${ }^{19}$ By the same token, violations of per se rules that the Supreme Court has established should result in automatic reversal if application of a harmless error standard would essentially alter the constitutional rule itself. If, for example, a failure to give warnings required by Miranda v. Arizona, 384 U.S. 436, 468-69 (1966), is harmless when the suspect is aware of his rights or is not indigent, as some courts have held, see State v. Bliss, 238 A.2d 848 (Del. 1968); State v. Carpenter, 211 Kan. 234, 505 P.2d 753 (1973); Commonwealth v. Wilbur, 353 Mass. 376, 231 N.E.2d 919 (1967), cert. denied, 390 U.S. 1010 (1968); People v. Post, 23 N.Y.2d 157, 242 N.E.2d 830, 295 N.Y.S.2d 665 (1968), that vitiates the per se quality of the Miranda rule, which requires warning even when persons are aware of their rights or are able to afford counsel. The issue concerning a confession obtained in violation of Miranda must be whether the admission of the confession was harmless-i.e., whether it had no effect-and not whether it was harmless to obtain it illegally. See People v. Schader, 62 Cal. 2d 716, 729-31, 401 P.2d 665, 673-74, 44 Cal. Rptr. 193, 201-02 (1965). See also Ibsen v. State, 83 Nev. 42, 422 P.2d 543 (1967). An analogous point can be made about Motes v. United States, 178 U.S. 458 (1900), in which a written accusation made at a preliminary hearing was introduced in evidence at trial, after the witness had escaped. In order to assess whether this violation of the confrontation clause was harmless, one must ask whether the result of the trial might have differed if the statement was not used in evidence; it is not proper to ask whether it would have differed if the witness had not escaped and had been available to testify, an inquiry that would overturn the finding of constitutional error in the first instance.

20407 U.S. 371 (1972). The result in Milton could also be explained by the cumulative evidence test, discussed in text accompanying notes 69-117 infra. 
inmate, was sharing Milton's cell. In ruling on Milton's habeas corpus petition, the Supreme Court declined to decide whether Langford's testimony violated Milton's fifth and sixth amendment rights. ${ }^{21}$ Instead, it held that "[a]ssuming, arguendo, that the challenged testimony should have been excluded, the record clearly reveals that any error in its admission was harmless beyond a reasonable doubt." 22 In reaching this conclusion, the Court did not deny that Langford's testimony was incriminating. ${ }^{23}$ Instead, it found harmless error because " $[t]$ he jury, in addition to hearing the challenged testimony, was presented with overwhelming evidence of petitioner's guilt, including no less than three full confessions that were made by petitioner prior to his indictment." ${ }^{24}$ The admissibility of the earlier confessions was not at issue. The Court's "review of the record ... [left] no reasonable doubt that the jury at petitioner's 1958 trial would have reached the same verdict without hearing Langford's testimony." 25 It thus apparently adopted the rule that erroneous admission of even incriminating evidence may be deemed harmless if the court is satisfied that other evidence in the case would in any event have led to the same result. ${ }^{26}$

${ }^{21}$ Milton's trial antedated the Supreme Court's decision in Massiah v. United States, 377 U.S. 201 (1964). The District Court had ruled against Milton on the ground that Massiah was not retroactive, 306 F. Supp. 929 (S.D. Fla. 1969), and the Court of Appeals, concluding that the case was "of the character that does not justify oral argument," affirmed on the basis of the District Court's opinion. 428 F.2d 463, $464 \mathrm{n} .1$ (5th Cir. 1970).

22407 U.S. at 372.

${ }^{23}$ In its statement of the facts, the Court said that "[t]he officer testified to incriminating statements made to him by petitioner ...." Id.

${ }^{24} I d$. at $372-73$.

${ }^{25} \mathrm{Id}$. at 377 .

${ }^{26}$ Another opinion unequivocally adopting the position that it is proper to determine harmlessness by focusing on the untainted evidence is the dissenting opinion of Mr. Justice Black in Bumper v. North Carolina, 391 U.S. 543, 554 (1968). Justice Black argued against reversing the "conviction of a defendant, because of the admission of illegally seized evidence, where other evidence conclusively demonstrates his guilt ...." Id. at 560. The Supreme Court reversed Bumper's conviction of felonious assault and rape because the police had illegally obtained Bumper's rifle, which had been introduced against him at trial. Bumper had allegedly used the .22-caliber rifle to force the rape victim to succumb and then to shoot both the victim and her boyfriend. Justice Black found the violation of the exclusionary rule harmless because "the overwhelming evidence in this case, even when the rifle and related testimony are excluded, amply demonstrates petitioner's guilt." Id. at 558. Justice Black's opinion did not attempt to explain away the prejudicial impact of such a central piece of evidence and the role that evidence played at trial.

The position on harmless constitutional error that Justice Black adopted in Bumper could derive more from his doubts about the wisdom of the fourth amendment exclusionary rule than from any convictions about harmless error as such. Id. at 560-61. 


\section{B. The Court's Statements Casting Doubt upon the Overwhelming Evidence Test}

Fahy v. Connecticut ${ }^{27}$ and Chapman v. California, ${ }^{28}$ two of the leading cases prior to Milton, ${ }^{29}$ cast doubt upon the propriety of the overwhelming evidence test. ${ }^{30}$ Bumper $v$. North Carolina ${ }^{31}$ also may be included in this group of cases. Because Milton in no way repudiates those cases, the case law appears inconsistent, the propriety of the overwhelming evidence test remaining an unsettled question. Alternatively, however, one might stress that these pre-Milton cases do not actually compel the proposition that focusing on the erroneously admitted evidence is the single test for assessing harmless constitutional error. Their holdings at least are reconcilable with the view that examining the untainted evidence is another proper means of determining harmlessness, even though in language they are far more ambiguous than Milton in supporting this view.

Fahy $v$. Connecticut concerned evidence seized in violation of the fourth and fourteenth amendments. Fahy had been convicted of painting swastikas on a synagogue. On appeal, the Connecticut Supreme Court concluded that the seizure and introduction at trial of a can of paint and a brush allegedly used in the crime violated the fourth and fourteenth amendments. That court deemed the error harmless, however, saying that the paint and brush "were, at most, cumulative" and "[ $t]$ he transcript of the evidence of the state's case in chief discloses overwhelming evidence of the guilt of the defendant."32

The swastikas had been painted between 4 a.m. and 5 a.m. At 4:40 a.m. an officer stopped Fahy and his codefendant in a

See, e.g., Kaufman v. United States, 394 U.S. 217, 231 (1969) (dissenting opinion); Berger v. New York, 388 U.S. 41, 70 (1967) (dissenting opinion). Moreover, Justice Black thought that the search in Bumper was constitutionally permissible, 391 U.S. at $555-57$, that the crime was "sordid," id. at 558, and that the prosecution had presented "an open-and-shut case of guilt," id. at 565 .

27375 U.S. 85 (1963).

${ }^{28} 386$ U.S. 18 (1967).

${ }^{29}$ Harrington v. California, 395 U.S. 250 (1969), another important pre-Milton harmless error case, is discussed in text accompanying notes 69-75 infra.

${ }^{30}$ Justice Brennan's dissenting opinion in Harrington $v$. California reflects that reading of Chapman. 395 U.S. 250, 255 (1969). See also People v. McNeil, 24 N.Y.2d 550, 555, 249 N.E.2d 383, 385-86, 301 N.Y.S.2d 503, 507, cert. denied, 396 U.S. 937 (1969) (Fuld, C.J., dissenting); Thompson, Unconstitutional Search and Seizure and the Myth of Harmless Error, 42 Notre Dame Law. 457, 464 (1967); 30 U. PitT. L. REv. 553, 557-58 (1969).

32375 U.S. at 93. 
car in the vicinity, discovering the paint and brush under the front seat. Later, after he learned of the painting of the swastikas, he went to Fahy's home and removed the paint and brush from Fahy's car without a warrant. Fahy was subsequently placed under arrest.

The Supreme Court defined its central inquiry as "whether there is a reasonable possibility that the evidence complained of might have contributed to the conviction." 33 In concluding that "it clearly appears that the erroneous admission of this illegally obtained evidence was prejudicial," ${ }^{34}$ Chief Justice Warren, writing for a majority of five, stated, "[o]bviously the tangible evidence of the paint and brush was itself incriminating." 35 Moreover, the evidence "was used to corroborate [police testimony] ... as to the presence of petitioner near the scene of the crime at about the time it was committed and as to the presence of a can of paint and a brush in petitioner's car at that time." 36 Additional testimony showed that the illegally seized paint and brush matched the markings on the synagogue. The tainted evidence also may have prompted admissions Fahy made to the police. Moreover, the evidence had a "cumulative prejudicial effect . . . upon the conduct of the defense at trial," for

it was only after admission of the paint and brush and only after their subsequent use to corroborate other state's evidence and only after introduction of the confession that the defendants took the stand, admitted their acts, and tried to establish that the nature of those acts was not within the scope of the felony statute under which the defendants had been charged. ${ }^{37}$

Chapman v. California was the next major Supreme Court case concerning harmless constitutional error. Teale and Chapman, convicted of robbing, kidnapping, and murdering a bartender, did not take the stand in their defense, a fact upon which the prosecuting attorney commented extensively. Similarly, the trial judge charged the jury that it could draw all reasonable inferences adverse to the defendants concerning information that the defendants could reasonably be expected to deny or

\footnotetext{
${ }^{33} I d$. at $86-87$.

${ }^{34} \mathrm{Id}$. at 91 .

${ }^{35} \mathrm{Id}$. at 81 .

${ }^{36} I d$. at 88 .

${ }^{37} I d$. at 91 (footnote omitted).
} 
explain because of facts presumably within their knowledge. Griffin v. California ${ }^{38}$ holding that comment on an accused's failure to testify unconstitutionally burdens his fifth amendment right not to incriminate himself, was not decided until Chapman was on appeal. After Griffin, the California Supreme Court conceded that petitioners had been deprived of a federal constitutional right but nevertheless affirmed the conviction. It found, as to defendant Teale, that combining his admissions with "the other substantial evidence, the proof of his guilt must be deemed overwhelming"; as to defendant Chapman, "the persuasive, circumstantial web of evidence which implicated her was not refuted"; and as to both, the court was "of the opinion that in the absence of the erroneous comments and instructions a result more favorable to defendants was not reasonably probable in view of the entire record ...., and that there has been no miscarriage of justice as to either Mrs. Chapman or Mr. Teale."39

On appeal, the United States Supreme Court, in an opinion by Mr. Justice Black, concluded that "it is completely impossible for us to say that the State has demonstrated, beyond a reasonable doubt, that the prosecutor's comments and the trial judge's instruction did not contribute to petitioners' convictions." ${ }^{40}$ In arriving at this conclusion, the Court stated:

The federal rule emphasizes "substantial rights" as do most others. The California constitutional rule emphasizes "a miscarriage of justice," but the California courts have neutralized this to some extent by emphasis, and perhaps overemphasis, upon the court's view of "overwhelming evidence." We prefer the approach of this Court in deciding what was harmless error in our recent case of Fahy $v$. Connecticut, 375 U.S. 85. There we said: "The question is whether there is a reasonable possibility that the evidence complained of might have contributed to the conviction." Id., at 86-87. . . . [This statement in Fahy], like the federal harmless-error statute, . . emphasizes an intention not to treat as harmless those constitutional errors that "affect substantial rights" of a party= An error in admitting plainly relevant evidence which possibly influenced the jury adversely

${ }^{39}$ People v. Teale, 63 Cal. 2d 178, 197, 404 P.2d 209, 220, 221, 45 Cal. Rptr. 729, 740,741 (1965).

40386 U.S. at 26. 
to a litigant cannot, under Fahy, be conceived of as harmless. ${ }^{41}$

Much of this Fahy-Chapman language seems to support the position that in assessing harmlessness of federal constitutional error, one should focus on the incriminating quality of the erroneously admitted evidence instead of weighing the untainted evidence in the case. ${ }^{42}$ The dichotomy the Court creates, in the above quotation from Chapman, between its Fahy approach of asking whether "the evidence complained of might have contributed to the conviction" and the California courts' approach suggests this view. One might, of course, argue that an error does not "contribute to the conviction" if other overwhelming evidence compels a verdict of guilty. But the Court, in these cases, seems to suggest a distinction between asking whether erroneously admitted evidence "possibly influenced the jury" (or, "might have contributed to the verdict") and asking whether, even if the error might have been influential, other untainted evidence would in any event have compelled the same result. This argument interprets Fahy and Chapman as suggesting a rule that, in assessing harmfulness, one should focus on the erroneously introduced evidence alone. That in both cases the state supreme court that was reversed had relied on the overwhelming quality of the evidence against the defendant reinforces this impression.

Yet the holdings of Fahy and Chapman are clearly reconcilable with the overwhelming evidence test as a supplemental means of determining harmless error. For, despite the state court statements, it seems that in neither case was there overwhelming evidence of guilt apart from the error. Indeed, in Fahy, the Supreme Court implicitly rejected the finding of overwhelming evidence that the state supreme court had made, finding that much of that evidence was not independent of the unconstitutionally admitted evidence but instead derived from it. ${ }^{43}$ And in Chapman, the Court, assessing the harmfulness of the

${ }^{41} \mathrm{Id}$. at 23-24 (footnotes omitted) (emphasis supplied).

42 One opinion adopting this reading of Chapman is Virgin Islands v. Bell, 392 F.2d 207, 209-10 (3d Cir. 1968). See also cases cited in note 30 supra.

43 "Examining the effect of this [illegally obtained] evidence upon the other evidence adduced at trial and upon the conduct of the defense, we find inescapable the conclusion that the trial court's error was prejudicial and cannot be called harmless." 375 U.S. at 87 . The Court's discussion of the other evidence in the case, id. at 88-91, also supports this reading. 
comments on failure to testify, not only stressed the pervasiveness of the comments, but also said:

[T]hough the case in which this occurred presented a reasonably strong "circumstantial web of evidence" against petitioners, $63 \mathrm{Cal} .2 \mathrm{~d}$, at 197, 404 P.2d, at 220, it was also a case in which, absent the constitutionally forbidden comments, honest, fair-minded jurors might very well have brought in not-guilty verdicts. ${ }^{4}$

In addition, the Chapman Court, immediately following its language suggesting that focusing on the error is the correct approach to harmless error, ${ }^{45}$ said: "Certainly error, constitutional error, in illegally admitting highly prejudicial evidence or comments, casts on someone other than the person prejudiced by it a burden to show that it was harmless," and harmlessness must be shown beyond a reasonable doubt. ${ }^{46}$ This suggests that such a showing of harmlessness is possible although the error itself is "highly prejudicial." Another indication that the weight of the untainted evidence may be a factor in determining harmlessness is the statement that "[i]n fashioning a harmless-constitutionalerror rule, we must recognize that harmless-error rules can work very unfair and mischievous results when, for example, highly important and persuasive evidence, or argument, though legally forbidden, finds its way into a trial in which the question of guilt or innocence is a close one." ${ }^{\prime 7}$ One leaves Chapman, then, with the view that the strength of the untainted evidence is not entirely irrelevant to a finding of harmless error, although it should not be given "overemphasis." 48

In the final analysis, the Court in Chapman does not formulate a coherent test for application of the harmless error doctrine. It is difficult to see the problem of the overwhelming evidence test as one of overemphasis versus proper emphasis. The test either is or is not a proper supplement to determining harmlessness by focusing on the incriminating qualities of the constitutional error. Chapman both disparages use of this test as a

44386 U.S. at $25-26$.

${ }^{45}$ See quotation in text accompanying note 41 supra.

46386 U.S. at 24.

${ }^{47}$ Id. at 22-23 (emphasis supplied). See also id. at 22: "We conclude that there may be some constitutional errors which in the setting of a particular case are so unimportant and insignificant that they may, consistent with the Federal Constitution, be deemed harmless, not requiring the automatic reversal of the conviction." (emphasis supplied)

${ }^{48}$ Id. at 23. 
supplement and speaks on the assumption that it is a proper one.

The Court's opinion in Bumper $v$. North Carolina similarly suggests that the exclusive way to assess harmlessness is to focus on the erroneously admitted evidence. The case involved a conviction of felonious assault and rape that the Supreme Court reversed because the defendant's improperly seized rifle, allegedly used in the crime, had been introduced against him at trial. Justice Black argued in dissent that the error was harmless because "the overwhelming evidence in this case, even when the rifle and related testimony are excluded, amply demonstrates petitioner's guilt." 49 The majority opinion's full discussion of the issue in text, however, states that "it was constitutional error to admit the rifle in evidence against the petitioner. . . . Because the rifle was plainly damaging evidence against the petitioner with respect to all three of the charges against him, its admission at the trial was not harmless error."50 That language focuses solely on the nature of the constitutional error to assess harmlessness.

In a footnote, ${ }^{51}$ however, the majority responded to Justice Black's assertion that the strength of the other evidence in the case rendered the error harmless. First it addressed Justice Black's "assumption that the petitioner was guilty" by saying that "it is not the function of this Court to determine innocence or guilt, much less to apply our own subjective notions of justice." That statement might suggest a repudiation of the overwhelming evidence approach, as I will develop below. ${ }^{52}$ "In view of the discursive factual recital contained in the dissenting opinion," however, the majority added that it did not believe that the untainted evidence against the petitioner was overwhelming. The footnote therefore makes the majority's position on determination of harmless error more equivocal than a reading of the text alone would indicate. ${ }^{53}$

49391 U.S. at 558 (dissenting opinion). For further discussion of this opinion, see note 26 supra.

${ }^{50} I d$. at 550.

${ }^{51} \mathrm{Id}$. at $550 \mathrm{n} .16$.

${ }^{52}$ See text accompanying notes 62-64 infra.

${ }^{53}$ Similarly, Justice Harlan, writing separately, first points out that the test is not and cannot be simply whether this Court finds credible the evidence against [the petitioner]. Crediting or discrediting evidence is the function of the trier of fact, in this case a jury. The jury's verdict is a lawful verdict, however, only if it is based upon evidence constitutionally admissible. When it is not, as it is not here, reversal rests on the oldest and most fundamental principle of our criminal jurisprudence-that a defendant is entitled to put the prosecution to its lawful proof. 
In addition, some Supreme Court statements clearly support exclusive focus on erroneously admitted evidence as the proper approach to harmless error, because they support a doctrine of automatic reversal for some constitutional errors. In Chapman, for example, the Court recognized that "there are some constitutional rights so basic to a fair trial that their infraction can never be treated as harmless error." $"$ A footnote cites three cases and characterizes the rights involved as "coerced confession," "right to counsel," and "impartial judge." 55 At least when those errors are involved, therefore, the Court has said that the overwhelming evidence test is inappropriate. What makes it inappropriate for those errors and not for others?

The errors designated in the footnote are of two types: (1) those that by their nature are especially damaging to a defendant, such as admission of a coerced confession, and (2) those that infect the entire trial process, such as the other two. ${ }^{56}$

391 U.S. at 552 (Harlan, J., concurring). While that statement might indicate a repudiation of the "overwhelming evidence" approach, see text accompanying notes 61-64 infra, Justice Harlan goes on to read the two approaches together to constitute one test:

[T] he question cannot be whether, in the view of this Court, the defendant actually committed the crimes charged, so that the error was "harmless" in the sense that petitioner got what he deserved. The question is whether the error was such that it cannot be said that petitioner's guilt was adjudicated on the basis of constitutionally admissible evidence, which means, in this case, whether the properly admissible evidence was such that the improper admission of the gun could not have affected the result.

Id. at 553 (emphasis supplied). Justice Harlan goes on to say that the untainted evidence, though strong enough to serve as the basis for a jury verdict against the petitioner, was not strong enough to compel that result.

54386 U.S. at 23 (footnote omitted).

${ }^{55} \mathrm{Id}$. at $23 \mathrm{n} .8$.

${ }^{56}$ Other categories of automatically reversible errors are possible. One such category is suggested in the discussion in note 19 supra. Another category appropriate for automatic reversal includes situations in which the prosecution deliberately committed the constitutional error or intentionally risked committing it. Instances of intentional violations are knowing use of perjured testimony, Miller v. Pate, 386 U.S. 1 (1967), or deliberate suppression of evidence favorable to the defense, Brady v. Maryland, 373 U.S. 83 (1963), Jackson v. Wainwright, 390 F.2d 288 (5th Cir. 1968); but of. Moore v. Illinois, 408 U.S. 786 (1972). The rule of automatic reversal should apply as well, however, when serious issues as to constitutionality have been raised and debated and the prosecution has nonetheless insisted upon the propriety of introducing the questionable evidence.

It is true that to the extent that objections must be made at trial to be preserved, those points that reach appeals courts always will have been raised below. Moreover, the prosecution implicitly claims that all the evidence it introduces is damaging to the defendant. To some extent, therefore, estoppel runs up against the very notion of harmless error rules, at least where the error occurs in the admission of evidence.

Whether one finds such governmental insistence upon the use of the improper evidence as would bring the automatic reversal rule into play is therefore a question of degree. But when an issue is litigated below in more than perfunctory fashion, governmental insistence despite debate as to the propriety of evidence seems inconsistent with 
Acceptance of the first set of errors as automatically reversible is logically inconsistent with the overwhelming evidence test. It is difficult to perceive why the weight of the untainted evidence should be irrelevant to certain especially prejudicial categories of constitutional error unless it is irrelevant as well when a particular, highly prejudicial error has occurred. The theory of the overwhelming evidence test is that regardless how prejudicial the constitutional error was, a conviction should not be reversed if the case against the defendant was so strong that conviction was inevitable. Acceptance of these errors as automatically reversible is, of course, perfectly consistent with the first approach to harmless error, looking only to the particular piece of illegally introduced evidence in assessing harmfulness.

It would, however, be consistent with the overwhelming evidence test to have a rule requiring automatic reversal whenever the constitutional error was such that by its nature it affected the entire trial process. If, for example, the defendant was deprived of his right to representation by an attorney, the weight of the evidence against him should be irrelevant because representation presumably would have affected the quality of the case against him. ${ }^{57}$ Alternatively, one could view this situation as an applica-

a later governmental position that the evidence in any event was unnecessary. Unless at the time of introduction the government deemed the evidence important, it seems unlikely it would have risked reversal by insisting on its use. Bram v. United States, 168 U.S. 532 (1897); United States v. Blair, 470 F.2d 331 (5th Cir. 1972); People v. Powell, 67 Cal. 2d 32, 429 P.2d 137, 59 Cal. Rptr. 817 (1967). True, if overwhelming evidence is the standard by which harmlessness is to be gauged, it may sometimes occur that the prosecution insists upon introducing evidence that proves unnecessary as the other evidence in the case develops. Even then estopping the government from asserting harmlessness does not seem unduly harsh. And if the nature of the error is the sole test of harmlessness, this category for automatic reversal seems unquestionably sound.

In this connection, it is noteworthy that many of the leading cases concerning harmless error involve errors that were committed before their unconstitutionality was established but were later ruled to be retroactive constitutional violations. The Griffin violation in Chapman $v$. California, for example, occurred before Griffin v. California, 380 U.S. 609 (1965), was decided. Fahy v. Connecticut involved a fourth amendment violation that occurred before the Supreme Court ruled that the fourth amendment applied to the states. The Bruton violations in Harrington v. California, 395 U.S. 250 (1969), and Schneble v. Florida, 405 U.S. 427 (1972), occurred prior to the Court's decision in Bruton v. United States, 391 U.S. 123 (1968). In those cases, therefore, a prosecuting attorney could claim unawareness of the unconstitutionality of his conduct much more successfully than if his violation occurred after the constitutional rule was announced. But $f f$. Brown v. United States, 411 U.S. 223 (1973). The principal danger in using a harmless error analysis in this situation is that it may be applied so as effectively to vitiate the Court's retroactivity ruling. $C f$. Hamling v. United States, 418 U.S. 87 (1974).

${ }^{57}$ The Court seems to have adopted this theory in the right-to-counsel area. See Chapman v. California, 386 U.S. 18, 43 (Stewart, J., concurring). But see Coleman v. Alabama, 399 U.S. 1 (1970); $c f$. United States v. Wade, 388 U.S. 218, 242 (1967). 
tion of the overwhelming evidence test, finding there is no compelling untainted evidence, or indeed any untainted evidence at all, because all the evidence in the case derives from the constitutional error. Forcing a legally incompetent person to stand trial is an error comparable in this respect. Trial by a biased tribunal is arguably of the same dimension. ${ }^{58}$

Coerced confessions, however, are clearly inconsistent with this defining principle for a category of automatically reversible errors. The only sense in which a coerced confession may be said to affect the entire trial process is that it may be so incriminating in the mind of the factfinder that it effectively forecloses the defense. To allow that rationale to support automatic reversal is to define that category according to the degree of prejudice inherent in the particular type of constitutional error-the explanation that is inconsistent with retention of the overwhelming evidence test.

It may be that, despite the Chapman statement, the Supreme Court would not in fact automatically reverse for introduction of a coerced confession without regard to the weight of other evidence in the case. ${ }^{59}$ Supreme Court holdings-as opposed to Supreme Court language-mandating automatic reversal since

${ }^{58} C f$. Coolidge v. New Hampshire, 403 U.S. 443 (1971), in which the majority overturned a conviction because the state attorney general had issued a search warrant in a case he was investigating (contrary to the fourth amendment's requirement that the issuing officer be neutral and detached). The majority did not mention the possibility of finding harmless error, $i d$. at 450 , although Justice Black, in dissent, argued that the error was harmless, id. at 501-02. Other errors that would be included if infection of the whole trial process were the defining principle for automatically reversible cases are violations of double jeopardy, see Price v. Georgia, 398 U.S. 323, 331 (1970), and cases in which the defendant has been convicted on the basis of an unconstitutional statute, see Stromberg v. California, 283 U.S. 359 (1931). In those situations, no trial and jury determination of guilt could be made without the constitutional irregularity. But if this definition of automatically reversible errors were adopted, a difficulty sometimes would arise in separating those situations in which the whole trial process could be said to be affected from those in which it could not. In Williams v. Estelle, 500 F.2d 206 (5th Cir. 1974), cert. denied, 420 U.S. 907 (1975), rev'g Williams v. Beto, 364 F. Supp. 335 (S.D. Tex. 1973), for example, the defendant was tried while wearing jail clothes. Should this be considered an error affecting the whole trial process or not? (The appeals court reversed the conviction, finding a due process violation and, contrary to the district court, a lack of overwhelming evidence of defendant's guilt.)

${ }^{59}$ Indeed, Harrington and Milton may so indicate. In both, confessions were held harmless. Harrington may be compatible with an automatic reversal rule for confessions in that it involved use of a codefendant's confession-a sixth amendment violation-that was held harmless. Milton, however, involved the defendant's confession, possibly obtained in violation of the right to counsel as defined in Massiah.

Milton and Harrington may, however, indicate simply that confessions are not per se reversible when they are "cumulative" with untainted evidence in the trial, see text accompanying notes 69-117 infra, but that it is nonetheless improper to apply an overwhelming evidence test to coerced confessions. 
the Supreme Court declared harmlessness a federal question in Chapman are nonexistent. Indeed, the language relied on in Chapman to support the existence of an automaticallyreversible-error category was simply descriptive of Supreme Court precedents. It might be explained simply as a relic of the pre-Chapman view that all federal constitutional errors require automatic reversal. ${ }^{60}$ In retreating from that position in Chapman, the Court distinguished prior holdings as compelled by the particularly prejudicial quality of the errors involved rather than squarely overturning the automatic reversal approach.

It is consistent with the overwhelming evidence test, which some of the case law supports, either to have no automatically reversible category or to have one that comports with the infectsthe-entire-trial-process explanation. Retaining a category of automatically reversible errors not limited to errors that affect all the evidence, however, would impugn the consistency of the Supreme Court's approach to harmless error determinations.

In sum, the case law on the content of the harmless error standard is less than lucid. There is some indication that Supreme Court opinions slip back and forth from one suggested standard to another, without explicit notice of the change, though the change could produce different results in many cases. If one is willing to strain to produce consistency, the single test most likely to emerge from Supreme Court precedents is one that would allow a finding of harmlessness in either of two circumstances: if the constitutional error complained of is by its nature unlikely to affect the result of litigation, or, even if it does appear influential, if the record shows as well overwhelming untainted evidence of the defendant's guilt. Although this is the position that most clearly emerges from the case law, it is my position that it would be preferable to eliminate the overwhelming evidence test and assess harmlessness solely by evaluating the impact of the erroneously admitted evidence, without regard to the weight of the untainted evidence in the case.

\section{Should The OverWhelming Evidence Test Be Retained?}

There are three reasons why the overwhelming evidence test should not be retained and the courts should confine them-

${ }^{60}$ But see Motes v. United States, 178 U.S. 458 (1900). 
selves to examining the tainted evidence (in context if necessary) in order to determine harmlessness:

1. An appellate court using the overwhelming evidence test usurps the jury's function far more significantly than an appellate court limiting its inquiry to an examination of the error.

2. The overwhelming evidence test disparages the notion that constitutional protection is due all citizens, the guilty as well as the innocent.

3. Findings of harmlessness under the overwhelming evidence test are much less subject to judicial review than findings of harmlessness under the first approach.

The first of these reasons is by far the most significant.

In one sense, the charge that an appellate court using the overwhelming evidence test usurps the jury's function could be leveled against any doctrine of harmless error. Whenever a court allows a conviction to stand despite an error, on the ground that the error is harmless, it is saying the jury would have reached the same result had the error not occurred. ${ }^{61}$ The cost and the imperfection of retrial as a general means of resolving whether an error was significant ${ }^{62}$ support allowing an appellate court to

${ }^{61}$ Instead of determining for itself the effect of error on the jury, a reviewing court could reverse the decision, thereby allowing a retrial without the error to serve as a test whether the error was influential; if the error truly was not determinative, the jury could find the defendant guilty again.

${ }^{62}$ Such an approach, which amounts to an overturning of the harmless error doctrine, would be expensive indeed if the rule were literally to allow a criminal conviction to stand only if the trial were wholly error-free. Criminal litigation, moreover, might be interminable. Even if the retrial avoided the original error, it probably would contain some error that, by hypothesis, would also necessitate reversal. In Kotteakos v. United States, 328 U.S. 750 (1946), the Court said that harmless error statutes, federal and state, resulted from a situation in which

courts of review "tower above the trials of criminal cases as impregnable citadels of technicality." So great was the threat of reversal, in many jurisdictions, that criminal trial became a game for sowing reversible error in the record, only to have repeated the same matching of wits when a new trial had been thus obtained.

Id. at $\mathbf{7 5 9}$ (footnote omitted). (Federal courts' habeas corpus jurisdiction, as currently interpreted, has been criticized for its interference with the finality of convictions. E.g., Bator, Finality in Criminal Law and Federal Habeas Corpus for State Prisoners, 76 Harv. L. REv. 441 (1963). While habeas results in continual reopening of final convictions, the effect of a rule that no error can be harmless would go further and prevent convictions from becoming final in the first instance.)

A rule of automatic reversal might, however, be reserved for errors of constitutional dimension, preserving the harmless error doctrine "to prevent matters concerned with the mere etiquette of trials and with the formalities and minutiae of procedure from touching the merits of a verdict," Bruno v. United States, 308 U.S. 287, 294 (1939), as the doctrine was intended to do. Indeed, until Fahy in 1963, Supreme Court 
rule in some cases that an error so clearly did not affect the verdict that retrial is unnecessary. If, however, in making this determination the court limits itself to the first approach, it usurps the jury's function far less significantly than if it decides harmlessness by assessing the weight of the untainted evidence. For the court's function under the first approach is limited to examining the error to determine whether, beyond a reasonable doubt, it was irrelevant to a finding of guilt, so that the reviewing court can be certain that the jury did not in fact give weight to it. Under the second approach, by contrast, the erroneously admitted evidence may have been very relevant indeed to the factfinder ${ }^{63}$ but the error may still be declared harmless on the ground that other overwhelming evidence supports the verdict.

The crucial difference between the appellate reviews under the tests is that a court that makes a finding of harmlessness under the overwhelming evidence test is not finding that the erroneously admitted evidence did not in fact affect the verdict. It may have been the erroneously admitted evidence and not the untainted evidence that persuaded the jury of the defendant's guilt, and yet the conviction may be allowed to stand. The court's affirmance simply indicates its opinion that the untainted evidence is so overwhelming that if the jury had been compelled to rely on it alone, it would have convicted. In so holding, the court

opinions lent support to the view that harmless error would not apply to constitutional errors. Chapman v. California, 386 U.S. 18, $42-45$ (1967) (Stewart, J., concurring); Tumey v. Ohio, 273 U.S. 510 (1927); Bram v. United States, 168 U.S. 532 (1897); Gibbs, Prejudicial Error: Admissions and Exclusions of Evidence in the Federal Courts, 3 VILL. L. Rev. 48, 67 (1957); 47 Colum. L. Rev. 450, 461 (1947); Note, Harmless Constitutional Error, 20 Stan. L. Rev. 83 (1967); see Kotteakos v. United States, supra at 764-65. But see Motes v. United States, 178 U.S. 458 (1900). Perhaps that would be the wisest disposition of the harmless error issue; the Court, however, definitively rejected it in Chapman.

Even disregarding the expense, automatic retrial for constitutional error has its own problems. The retrial does not provide a precise experimental test of how the jury would have decided the case had the constitutional error not occurred. When the untainted evidence, though sufficient to support a finding of guilt, is less than overwhelming, a change in verdict might result from a change in composition of the jury on retrial rather than from the error's absence. But insofar as the new verdict is based on the same evidence as at the first trial and represents a fair determination that the defendant is not guilty, the change in result is no cause for concern though a verdict of guilty would have been sustainable. Similarly, a change in verdict may result from the defense learning from strategic errors committed the first time around, or from a change in strategy by the defense in light of its increased knowledge of the prosecution's case. The most worrisome reason for a change in verdict at the retrial, however, is a disappearance of witnesses or of other evidence important to the prosecution's case. Because either side's evidence may not be available at a second trial, a retrial may differ significantly from the model of the original trial absent the constitutional error.

${ }^{63}$ As it was in both Bumper and Milton. 
is not passing upon what the jury did; it is not determining the propriety of the evidence on which the jury relied. Because it is ruling instead upon what the jury would do if forced to rely on different evidence, it is substituting itself for the jury as factfinder. Such a practice is difficult to reconcile with the accepted rule that a trial judge may not direct a verdict against a defendant in a criminal case, regardless of the strength of the evidence against him. ${ }^{64}$

The first approach is significantly less vulnerable in this respect. Under the first approach, the court rules that the nature of the erroneously admitted evidence is such that it could not have affected the jury, so the jury must have relied on other (sufficient if not overwhelming) evidence in the first instance, the same evidence it would rely on again were there a retrial. It rules that a remand would result in a conviction of defendant on the same evidence on which he has already been convicted. This is unlike the overwhelming evidence test, under which the court denies that the error affected the verdict, but only because of its view of what the jury would do in an essentially different situation than the one that was presented to it.

The practice is also inconsistent with the notion that all accused individuals, both guilty and innocent, are entitled to a fair trial and to all the protections of the Constitution. Its effect is that a trial in which a damaging constitutional error was made is acceptable for an individual who is undoubtably guilty - that is, against whom there is overwhelming evidence. By contrast, under the first approach, a reviewing court must always examine whether the trial was an essentially fair one, in which the conviction was not based upon any constitutional error that did occur.

There is another, more pragmatic, reason for favoring the first approach without the overwhelming evidence test: the greater ease of review which the first approach affords. It thus

${ }^{64}$ If the sixth amendment requires that rule, it would seem to preclude an overwhelming evidence test for errors of constitutional dimension as well.

One reason for requiring that a jury pass on the case may be so that it can exercise mercy, regardless of the weight of the evidence, if it so chooses. But even if that explains the directed verdict rule, admitting illegally obtained evidence may determinatively affect a jury's decision whether to render clemency. Accordingly, the directed verdict analogy still obtains. There is, of course, a distinction between prohibiting directed verdicts and prohibiting harmless error rulings: directed verdicts are quite unnecessary in ordinary circumstances because the judge can simply allow the case to go to the jury, which is convened and presumably able to render a verdict. Prohibiting harmless error rulings would be far more expensive, in that a new trial would have to be ordered. 
makes appellate review a more effective check on misuse of the harmless error doctrine.

In the past, state and lower federal courts have sometimes used the harmless error doctrine to evade full compliance with constitutional requirements, ${ }^{65}$ acknowledging constitutional rules in theory, but calling infractions harmless at particular trials in circumstances where such rulings were questionable. If overwhelming untainted evidence is a test of harmlessness, Supreme Court or other appellate review of such rulings is very difficult. Few cases will be reviewed in full, and the holdings in those will lack precedential import, for the overwhelming evidence test is based on all the evidence in the record except the erroneously admitted evidence. Under the overwhelming evidence test, plenary review of a harmless error ruling entails a commitment to examine in detail what may be a very complicated and extensive record $^{66}$ in order to weigh the evidence, only to render a decision devoid of precedential value because so closely tied to the facts of the case. ${ }^{67}$ Under the first approach, it would be more difficult for recalcitrant courts to avoid constitutional rules by paying them lip service and then calling infractions harmless. ${ }^{68}$

${ }^{65}$ See generally Brief for Respondent at 25, Chapman v. California, 386 U.S. 18 (1967); R. Traynor, The Riddle of Harmless ERror 43 (1970); Cameron \& Osborn, When Harmless Error Isn't Harmless, 197I LAw \& THE Social ORder 23 (written by a Justice of the Arizona Supreme Court); Manwaring, California and the Fourth Amendment, 16 Stan. L. Rev. 318 (1964); Mause, Harmless Constitutional Error: The Implications of Chapman v. California, 53 MinN. L. REv. 519 (1969); Thompson, Unconstitutional Search and Seizure and the Myth of Harmless Error, 42 NOTRE Dame LAw. 457 (1967) (written by the Chief Justice of the Nevada Supreme Court); Note, Harmless Constitutional Error, 20 STAN. L. REv. 83, 86 (1967). Examples of cases that seemingly evidence this tendency are United States v. Jackson, 429 F.2d 1368, 1372-73 (7th Cir. 1970); Commonwealth v. Wilbur, 353 Mass. 376, 231 N.E.2d 919 (1967), cert. denied, 390 U.S. 1010 (1968); State v. Hudson, 281 N.C. 100, 187 S.E.2d 756 (1972), cert. denied, 414 U.S. 1160 (1974).

${ }^{66}$ Consider, for example, the boast of the court of appeals in United States v. Fassler, 434 F.2d 161 (9th Cir. 1970), cert. denied, 401 U.S. 1011 (1971), that it had carefully studied the entire 564-page transcript in order to establish a defendant's guilt beyond a reasonable doubt. Or consider Harrington, in which a 427-page record confronted the Justices.

${ }^{67} \mathrm{Justice}$ Brennan made this point in his dissent in Harrington: "By its nature, the issue of substantiality of evidence admits of only the most limited kind of appellate review. Thus, the Court's rule will often effectively leave the vindication of constitutional rights solely in the hands of trial judges." 395 U.S. at 256.

${ }^{68}$ The ease of review under the first approach does change, of course, according to how the error is viewed. If the error is such that the court can rule on its harmlessness apart from the facts of the case, it can look only to the disputed evidence to decide whether it is of a nature likely to be influential with a jury and thereby avoid working through the record altogether. When, however, the inquiry must be whether the challenged evidence is damaging in context, because of its interaction with untainted evidence in the case, the scope of the inquiry most closely approximates that required by the overwhelming evidence test. But even here the focus of review is substantially nar- 


\section{The Cumulative Evidence Test-A Third Distinct ApProach}

Another general test for harmless constitutional error that is discernible from the cases focuses on whether the tainted evidence was "merely cumulative"-that is, whether untainted evidence that says the same thing as the excluded evidence remains in the case. The theory is that the tainted evidence added nothing material to the government's case, and the error is therefore harmless. The principal problems with the test are ones of definition.

\section{A. Harrington v. California}

Harrington $v$. California ${ }^{69}$ is the chief case supporting the existence of a cumulative evidence test. In Harrington, the Supreme Court held harmless the introduction of confessions of two codefendants who did not take the stand at petitioner's trial for felony murder and attempted robbery. The use of those confessions was constitutional error under Bruton v. United States. ${ }^{70}$ The Court, in an opinion by Mr. Justice Douglas, held that the evidence the unconstitutional confessions provided was cumulative both with a statement of Harrington placing himself at the scene of the crime and a confession of a third codefendant that did not violate Bruton. The Court also said:

[A]part from [the erroneously admitted confessions] the case against Harrington was so overwhelming that we conclude that this violation of Bruton was harmless beyond a reasonable doubt, unless we adopt the minority view in Chapman ... that a departure from

rower and the process correspondingly easier than under the overwhelming evidence test. For the defendant, in putting forth a case for the damaging effects of the evidence in context, will point to the particular aspects of the untainted evidence relevant to his argument; the entire record will not be relevant, but only those portions containing evidence alleged to interact in a damaging manner with the illegal evidence, and the parties can be counted on to bring forth that evidence in argument. If the prosecution disputes the defendant's analysis, it should offer an explanation why the interaction was not harmful, and perhaps point to other evidence making it harmless. But as long as neither the prosecution nor a lower court can rely on the overwhelming weight of the untainted evidence taken as a whole, the reviewing court need look only to particular parts of the record pointed out to it, and then only to trace the effects of the particular illegal evidence on the verdict; it need not peruse and weigh the evidence in the record as a whole. Review is substantially more limited than under the overwhelming evidence test, although this approach may produce some holdings limited to the facts of a particular case.

${ }^{69} 395$ U.S. 250 (1969).

70391 U.S. 123 (1968). 
constitutional procedures should result in an automatic reversal, regardless of the weight of the evidence. ${ }^{71}$

The opinion went on to say:

We admonished in Chapman ... against giving too much emphasis to "overwhelming evidence" of guilt, stating that constitutional errors affecting the substantial rights of the aggrieved party could not be considered to be harmless. By that test we cannot impute reversible weight to the two confessions.

We do not depart from Chapman; nor do we dilute it by inference. We reaffirm it. We do not suggest that, if evidence bearing on all the ingredients of the crime is tendered, the use of cumulative evidence, though tainted, is harmless error. Our decision is based on the evidence in this record. The case against Harrington was not woven from circumstantial evidence. It is so overwhelming that unless we say that no violation of Bruton can constitute harmless error, we must leave this state conviction undisturbed. ${ }^{72}$

The overwhelming untainted evidence against Harrington to which the Court referred consisted in part of a statement by Harrington. The statement, which was not a confession, placed Harrington at the scene of the crime and contained an admission that he fled with the other three. In it, Harrington also admitted that after the murder he shaved off his moustache and dyed his hair. The testifying codefendant's confession placed Harrington inside the store with a gun, and the testimony of eyewitnesses placed Harrington at the scene. The erroneously admitted confessions did not mention Harrington by name but described him and placed him at the scene of the crime. (In the Court's statement of facts, it is unclear to what extent either the eyewitnesses or the nontestifying codefendants described Harrington as an active participant in the crime instead of simply confirming his admission that he was present. ${ }^{73}$ )

It is difficult to state with any certainty exactly what test for harmless error the Harrington opinion adopts. Although it says

71395 U.S. at 254 (citations omitted).

${ }^{72}$ Id. (citations omitted).

${ }^{73}$ For a somewhat different version of the facts, see note 87 infra. 
that the overwhelming evidence test should not be given "too much emphasis," 74 much of the opinion reads as if the reason for the finding of harmlessness is the overwhelming nature of the untainted evidence against Harrington. Indeed, the opinion twice (at the end of each of the above quotations) speaks as if the only alternatives for determining harmlessness are an overwhelming evidence test, on the one hand, and a rule of automatic reversal on the other. In other ways, though, the opinion suggests there may be something about the way the tainted evidence relates to the untainted evidence that is pertinent to the finding of harmlessness, ${ }^{75}$ not simply the quantity or weight of the untainted evidence. This suggests a third variant by which harmless error might be determined, a variant I will refer to as the cumulative evidence test.

\section{B. Distinguishing Cumulative Evidence from the Other Tests}

Whether or not a cumulative evidence test explains the result in Harrington, this test does represent a distinct approach to harmless error. That there is a difference between this test and the first approach is clear. Applying the first approach to the facts of Harrington, one could not find harmlessness; examining the nontestifying codefendants' confessions, one would conclude that they incriminated Harrington. ${ }^{76}$ The cumulative evidence test, on the other hand, is like the overwhelming evidence test in that it allows a finding of harmlessness despite the conclu-

${ }^{74}$ Id. But of. text accompanying notes $48-49$ supra, criticizing the Court for making the same point in Chapman v. California, 386 U.S. 18 (1967).

75395 U.S. at 253-54.

${ }^{76}$ The Court itself appeared to reach this conclusion in Harrington. The argument apparently was made that the confessions were not damaging to Harrington because they did not refer to him by name. In one he was called "the white boy" and "this white guy" and described by age, height, and weight. In the other he was called a blondheaded fellow, "the white guy," and "the Patty." In its opinion, the Court said:

Petitioner argues that it is irrelevant that he was not named in Cooper's and Bosby's confessions, that reference to "the white guy" made it as clear as pointing and shouting that the person referred to was the white man in the dock with the three Negroes. We make the same assumption.

395 U.S. at 253. The Court went on nevertheless to hold the error harmless under the overwhelming evidence test and/or the cumulative evidence test.

Indeed, a statement by participants that a Caucasian was an accomplice could itself have been detrimental to Harrington, for one point in his favor was that two of the eyewitnesses who identified him as a participant had previously told the police that all four participants were Black. Id. 
sion that the error itself is prima facie incriminating, as long as it is somehow cumulative with other untainted evidence in the case. The interrelation between the first approach and the cumulative evidence test can thus be summarized as follows: the cumulative evidence test (again, like the overwhelming evidence test) is relevant only to errors that would not be harmless under the first approach. Any error that is harmless under the first approach will necessarily be found harmless. The cumulative evidence test and the overwhelming evidence test provide means of holding harmless some errors that would appear harmful under the first approach alone.

The cumulative evidence test differs also from the overwhelming evidence test, as the following example illustrates. Suppose a defendant in a criminal case has on five occasions made identical statements to the police. The first four were volunteered and spontaneous. The police solicited the fifth under circumstances requiring Miranda warnings, which were not given. All five statements are introduced at trial, the fifth unconstitutionally. None of the statements admits guilt; they all deny it. But each is incriminating because it places the defendant at the scene of the crime and thereby provides a necessary link in the chain of evidence against him. The cumulative evidence test clearly would deem harmless the error in admitting the fifth statement, because by hypothesis it is identical in content to the four previously obtained, untainted statements. The overwhelming evidence test, standing alone, would allow a finding of harmlessness only if the untainted evidence was compelling, as opposed to simply sufficient to support the jury's verdict. That might or might not be true in the hypothetical above. Of course, a court could follow both the overwhelming evidence test and the cumulative evidence test, allowing a finding of harmlessness if either approach were satisfied; the point is simply that the tests can be applied separately and can lead to different results. Similarly, one can hypothesize a case in which the overwhelming evidence test leads to a conclusion of harmlessness, but no untainted evidence is strictly "cumulative" with the tainted evidence, so that if that test stood alone, a finding of harmlessness would not be possible. The interrelation of the overwhelming evidence test and the cumulative evidence test depends, however, upon how the requirement of "cumulativeness" is viewed, as I will now discuss. 


\section{Requirements of the Cumulative Evidence Test}

1. Cumulativeness Defined-The Case for a Narrow Standard

One can apply the cumulative evidence test in such a way that it slips into the overwhelming evidence test. Take, for example, a case in which a codefendant's confession, erroneously admitted in violation of Bruton, implicates the complaining defendant in a theft of merchandise from a warehouse. Yet also in evidence, and undisputed, are police photographs of the robbers, taken during commission of the crime, which clearly attest to the defendant's guilt. ${ }^{77}$ In such a case one might say that the Bruton violation was "cumulative" in that it simply offered evidence of a proposition that was clear: the defendant's guilt. Viewed in this way, the cumulative evidence test is satisfied by a finding of overwhelming evidence: two pieces of evidence, both damaging to the defendant on the ultimate issue-guilt-are thereby deemed "cumulative" or "merely corroborative" of each other. ${ }^{78}$

The requirement of cumulativeness can, however, be defined more narrowly so that the test is distinct from one requiring overwhelming evidence. So defined, the tests are wholly independent of each other in the sense that either may, in particular situations, be more generous to a finding of harmlessness than is the other. Not only can the cumulative evidence test be satisfied when the overwhelming evidence test is not (as the example above involving five consecutive confessions illustrates), but also the overwhelming evidence test can be satisfied when the cumulative evidence test is not (as the Bruton-violation-police-photos case illustrates, at least if confessions and photographs cannot be cumulative with each other).

The cumulative evidence test can vary tremendously according to how its terms are defined. One might say that the test whether two pieces of evidence are cumulative is simply whether

77 This example is based on Brown v. United States, 411 U.S. 223 (1973).

${ }^{78}$ The tests still would be equivalent only in the sense that a finding of overwhelming evidence would satisfy the cumulativeness test, and not vice versa. That is, there would still be instances of cumulativeness where the untainted evidence was not overwhelming, as in the hypothetical discussed in the text. So defined, therefore, the cumulativeness test sometimes would be more generous in allowing findings of harmlessness than would the overwhelming evidence test, and it would never be stricter. 
they impose the same harm on the defendant. Even then the test would vary tremendously according to whether the "harm" could refer to an ultimate fact like "guilt" or whether the specific facts disclosed in the two pieces of evidence must also be the same. And, if the latter, it would still have to be resolved how specific the facts disclosed must be or, phrased differently, how identical in incriminating content the two pieces of evidence claimed to be cumulative must be.

Instead of requiring only that evidence, to be cumulative, must cause the same harm (however defined), one might require as well that it be of the same kind. Again, marked variations on what is meant by the "same kind" are possible. One might mean simply that the fruits of a search could not be cumulative with a confession, ${ }^{79}$ but that confessions could be cumulative with each other. Or one might require that, to be "of the same kind," confessions must as well be made by the same person. ${ }^{80}$ Or one might add as well that the confessions must be made under the same circumstances, or that they must be very similar in wording, and so on, ad infinitum. The simple statement, then, that error will be considered harmless if it is "merely cumulative" of untainted evidence in the record (and the cases do not state even this in certain terms) tells us little indeed about the bases for a determination of harmlessness.

One can minimize some of the dangers of a cumulative evidence test by adopting one of the narrower definitions of "cumulativeness." Before finding that tainted evidence is merely cumulative with untainted evidence, one could require that the untainted evidence harm the defendant in the same way, and also that it be of the same kind; and one can define those terms as well narrowly: confessions, for example, can be cumulative only with other confessions and one can require as well that they be identical in the facts they directly reveal and not just in facts that may be derived from them.

The danger in finding less similar sources of evidence to be cumulative is that, in fact, they may have a markedly different impact on the jury. ${ }^{81}$ An objection can be made to the cumula-

${ }^{79}$ This would mean also that photos and Bruton violations could not be cumulative with each other, thereby disposing of the cumulativeness argument in the example in the text. Text accompanying note 76 supra.

80 This rule would never allow Bruton errors to be cumulative with confessions obtained in violation of the self-incrimination clause of the fifth amendment.

${ }^{81}$ Consider, for example, the different effect of various types of evidence in People 
tive evidence test similar to that leveled against the overwhelming evidence test: in apparent contradiction to precedents disallowing directed verdicts in criminal cases, the overwhelming evidence test allows a finding of harmlessness because of a feeling that a different jury, possibly acting on different evidence than the original convicting jury acted on, would necessarily find the defendant guilty. A court following a broad version of the cumulative evidence test might similarly displace the jury. The objection is much less potent, however, if one requires, in a finding of cumulativeness, that the untainted evidence and the cumulative tainted evidence be very much alike. In that circumstance, while admitting that the tainted evidence may have persuaded the jury of guilt, a court applying the cumulative evidence test could argue nevertheless that the evidence the jury otherwise would have heard is so very like the evidence it actually heard that it clearly would have acted in the same way had no constitutional error occurred. (Note that one cannot say here that the next jury necessarily would convict. In this sense, the test is less stringent in reversing for constitutional error than the overwhelming evidence test. For the case against the defendant may, under the cumulative evidence test, be simply sufficient to support a verdict of guilty and not constitute an overwhelming case of guilt. What is true under the cumulative evidence test, but not necessarily under the overwhelming evidence test, is that the jury that has convicted passed on essentially the same evidence as it would have if no constitutional error had occurred. ${ }^{82}$ In this respect, the cumulative evidence test is much closer to the first approach than is the overwhelming evidence test.)

v. Jacobson, 63 Cal. 2d 319, 405 P.2d 555, 46 Cal. Rptr. 515 (1965). Although several witnesses at the penalty hearing testified that the defendant had no remorse after slaying his baby, that evidence may have had significantly less impact than the tapes of the defendant's own voice showing no remorse.

${ }^{82}$ A case of successive incriminating statements by the defendant, one of which should not have been admitted under Miranda, illustrates the differences among the three approaches. The first approach would require reversal because the unconstitutionally obtained and admitted statement is itself incriminating and might, rather than the others, have persuaded members of the jury of guilt. Under the cumulative evidence approach, by contrast, one might say that regardless of which confession or confessions actually were persuasive, all are so similar that the case would be substantially unaffected by exclusion of the tainted statement. The overwhelming evidence test would find harmlessness only if the untainted evidence compelled a conclusion of guilt, and would allow the court to look at evidence quite unlike the tainted evidence and independent of it to make this finding. 
2. Probativeness of the Untainted Evidence-The Case for Requiring Indisputability

Requiring a greater degree of similarity for evidence to qualify as cumulative not only decreases the likelihood that the two pieces of evidence would have a different impact on the jury but also makes it more likely that they are of equal probative effect. It of course would be senseless to hold harmless the admission of tainted evidence because it is very similar to properly admitted evidence, when the improper evidence is the more probative. Relative probativeness is not, however, always easy to judge. The only way one can be certain that the two pieces of evidence are equally probative on every fact is if they are identical in wording, circumstances under which they were given, confessor, and so on. How close one should come to requiring that they be identical is the problem. Rather than purporting to draft a test that would resolve this issue in terms of the degree of equivalence in any given case, one can simply require, separate from the requirements of similarity between the tainted and untainted evidence, that the untainted evidence must be of equal or superior probative effect or, in other words, that the untainted evidence must be equally or more incriminating than the tainted evidence. Alternatively, one can phrase the test as requiring a beyond-a-reasonable-doubt finding that the factfinder could not have believed the tainted evidence without believing the untainted evidence.

One could instead require, more strictly, that the cumulative, untainted evidence be indisputable (or, phrased differently, that the factfinder must necessarily have believed the untainted evidence). There are several advantages to adopting this stricter view. Before exploring them, however, we should examine some cases in which harmlessness has been an issue, to see how this requirement would operate.

The findings of harmlessness in Motes $v$. United States ${ }^{83}$ and in Harrington $v$. California ${ }^{84}$ are consistent with this strict test. In Motes, the petitioner, Columbus Motes, had been tried together with four codefendants for conspiracy to injure a person in the exercise of his federal constitutional rights, namely to murder one Thompson. A sixth coconspirator was originally indicted, but testified at the preliminary hearing concerning the guilt of 
all of them and subsequently pleaded guilty. He fled before the trial, where he was to be a witness, and his preliminary hearing testimony was introduced against the five defendants. Motes, testifying at trial, claimed that he and the absentee witness had committed the murder alone and that none of the other four defendants had participated at all. The Supreme Court held that the admission of the absentee conspirator's statement violated the confrontation clause, but that the violation was harmless as to Motes because he had offered conclusive proof of his own guilt.

If Motes' admission had been independent of the tainted evidence, ${ }^{85}$ and if Motes in no way controverted it, it would seem proper to hold the constitutional error harmless as to him because the facts to which the tainted evidence related would appear indisputable. The Supreme Court held the error harmless on this theory, without adverting to the issue whether Motes' testimony derived from the tainted evidence. ${ }^{86}$ Similarly, in Harrington $v$. California, the unconstitutionally admitted evidence (again, a violation of the confrontation clause) simply duplicated, in the Court's view, ${ }^{87}$ Harrington's own admission, which the defense did not otherwise dispute. The issue to which the erroneously admitted evidence related-Harrington's presence at the scene of the crime-was thus effectively withdrawn from the case.

${ }^{85}$ The Court's opinion does not make clear the temporal sequence between the constitutional error and the in-court admission. For discussion of the fruits problem generally, see notes 105-09 infra \& accompanying text.

${ }^{86}$ Similarly, in Vasquez v. State, 254 Ind. 472, 260 N.E.2d 779 (1970), cert. denied, 401 U.S. 1012 (1971), and in Greer v. State, 252 Ind. 20, 245 N.E.2d 158 (1969), the Indiana Supreme Court found Miranda violations harmless because in each case the defendant reiterated the incriminating facts on the witness stand. Again, assuming no fruits problem, the holding seems correct on the theory that the defendants' admissions effectively removed from dispute the matters to which the tainted evidence related. (In fact in Vasquez, a rape prosecution, there appears to be another problem: a discrepancy in fact between the untainted and the "cumulative" tainted testimony. In the latter, the defendant claimed to have left a bar $2 \frac{1}{2}$ hours earlier than in the former. The court does not explain how this relates to the charge, nor indeed does it disclose when the rape occurred. The discrepancy between the two pieces of evidence should prevent the case from qualifying for cumulative evidence treatment. For a discussion concerning necessity of similarity between the tainted and untainted evidence, see text accompanying notes 79-82 supra.

${ }^{87}$ This Article's discussions of the Harrington facts reflect the majority's version of the case. They see the factual issue to which the tainted evidence addressed itself as whether Harrington was present at the scene of the crime. See 395 U.S. at 252-53. Justice Brennan sees the central factual issue, however, as whether Harrington participated in the crime of attempted robbery, not whether he was present at the scene of the crime. $I d$. at 256. The illegally admitted confessions implicated Harrington in actual participation in the crime, while Harrington's admission went only to his presence at the scene. Under this view, the illegally admitted evidence was clearly not 
In both cases the untainted evidence, which the tainted evidence duplicated, was effectively indisputable. To require for a finding of cumulativeness that the "incriminating" facts to which the tainted evidence attests must be effectively beyond dispute seems to impose an extremely harsh limitation on the cumulative evidence test: It would mean that the cumulative evidence test would limit harmlessness to situations in which the unconstitutionally admitted evidence in retrospect was wholly unnecessary to the case, just as the first approach limits harmlessness to situations in which the erroneously admitted evidence was irrelevant or of trivial consequence.

Yet the condition that the cumulative untainted evidence be effectively not in dispute is not infrequently satisfied in cases, and there is reason to require it. For if doubt is raised as to the validity of the untainted version of the facts, one cannot be certain whether the jury believed that version or not. When the tainted evidence is cumulative of evidence the jury disbelieved (or, alternatively, evidence it would not have believed but for the reinforcing effect of the tainted evidence), the tainted incriminating evidence was obviously important to the disposition of the case. Let us imagine, for example, a case in which the prosecution has introduced into evidence two confessions by the

cumulative in content with the untainted evidence. Justice Brennan's view is borne out by examination of the record in the case. Harrington admitted (in a statement to the police) that he drove to the store with his codefendants, remained in the car for a while, and then decided he needed some cigarettes. He did not admit any intent or desire to participate in a crime. Upon entering the store, he found himself in the midst of an ongoing robbery. Record at 363 . One of the illegally admitted confessions, by contrast, referred to Harrington as one of "the other two fellows . . involved in this," id. 279 (emphasis supplied), and said Harrington went into the store with the two other codefendants to make sure everything was all right, while the fourth robbed the till. Record at 276-77, 290. The other placed Harrington at the scene in a manner that suggested he participated in the robbery. See id. 204-05, 259. It is true that another codefendant's confession, legally admitted, implicated Harrington by placing him in the store with a gun while the crime was committed. But as Justice Brennan pointed out, that codefendant's testimony was largely self-serving and might for that reason have been discredited: the gun was found in his possession after the robbery, and he testified that he obtained it from Harrington, who had it during the robbery. The remaining untainted evidence against Harrington, the testimony of two victims of the crime, was weakened because the victims had earlier told the police that all the participants in the crime were Black, whereas Harrington was Caucasian. Moreover, it is not clear whether they only placed him at the scene or testified concerning his participation as well. In short, the untainted evidence in the case appears to satisfy neither the overwhelming evidence test nor the cumulative evidence test. On Justice Brennan's version of the facts, it is easy to conclude with him that the illegally admitted confessions "might well have tipped the balance in the jurors' minds in favor of conviction. Certainly, the State has not carried the burden of demonstrating beyond a reasonable doubt that these two confessions did not contribute to Harrington's conviction." 395 U.S. at 257. 
defendant. The appellate court holds that it was error under Miranda to introduce the second confession, but it upholds admission of the first confession, which the defense had argued was involuntary because extracted by physical force. The defense made the same argument to the jury in order to show the unreliability of the first confession. In that circumstance, the second confession should not be declared harmless because duplicative of the first, for the jury may not have credited the first confession at all, or they may have decided to credit it only because the erroneously admitted confession duplicated it.

The discussion thus far suggests that the cumulative evidence test should not be satisfied if the reliability of the untainted duplicative evidence is drawn into question by the defense. Yet the suggested requirement for the cumulative evidence test goes further by requiring that the untainted evidence, even if the defense says nothing concerning it, must be indisputable. The reason lies in the constitutional right of the accused to require the state to prove him guilty beyond a reasonable doubt and in his constitutional right not to take the stand. A test allowing incriminating error to be harmless because the defendant had not affirmatively contested it would impinge upon these rights. Thus, if the state presents a case that depends in part upon facts derived from a constitutional error, the defendant's inability or unwillingness to contradict those facts cannot be the basis for a finding of harmlessness. A finding of harmlessness should be possible only if there is an affirmative indication in the record (provided by the petitioners' own statements in Motes and Harrington) that the defendant accepts the facts the erroneously admitted evidence supports; or if the untainted evidence is otherwise indisputable; 88 or if the facts in question are demonstrably irrelevant to the issue of guilt or innocence and therefore harmless under the first approach as well as the cumulative evidence approach.

${ }^{88}$ Another twist to a rule requiring that the untainted evidence be indisputable, not simply undisputed, is shown in Brown v. United States, 411 U.S. 223 (1973). There the petitioners did dispute the admissibility of evidence seized in-a search. The United States Supreme Court, however, held the evidence constitutionally admissible and also held that the petitioners lacked standing to challenge it. Because the Supreme Court ruled in the very case that the untainted evidence was admissible, and because the challenge to the evidence did not call into question its reliability, the propriety of the evidence should be viewed as indisputable even though the petitioners actually disputed it. In this connection, however, unlike those instances discussed in the text, a rule of indisputability is more favorable to the prosecution than a rule looking simply to whether the defendants have in fact challenged the evidence. 
A number of decisions illustrate the difference between a rule requiring that the untainted evidence be indisputable concerning the cumulative facts and rules requiring something less. Brown v. United States, ${ }^{89}$ for example, seems consistent with the stricter view. In that case the Supreme Court held harmless the unconstitutional admission of the codefendants' confessions (violative, again, of Bruton) because the untainted evidence included the defendants' own confessions, admitted without objection. ${ }^{90}$ Similarly, in United States $v$. Spinks, ${ }^{91}$ the United States Court of Appeals for the Seventh Circuit declined to reverse a conviction where confessions of both the defendant and his codefendant were introduced in evidence; the codefendant did not take the stand; and there were "no substantial factual differences"92 between the confessions. The complaining defendant did not contest his own confession..$^{93}$

This application of the harmless error doctrine, however, is valid only if the defendant challenges neither the voluntariness nor the accuracy of his confession. If he challenges either, his own confession may still be superior to the tainted one in probative effect, in the sense that an appellate court might find the defendant's confession more believable than the codefendant's, but the jury might have disbelieved the untainted evidence, and might therefore have given some weight to the tainted evidence in convicting. It is this point that is ignored in other decisions.

In Schneble v. Florida, ${ }^{94}$ for example, the Bruton violation involved a codefendant's confession partially implicating Schneble in a murder. Schneble's own confession also was introduced at trial. He did not offer evidence to contradict his confession's details nor did he take the stand. But the evidence did show that Schneble had denied his guilt to the police before making his

${ }^{89} I d$.

${ }^{90}$ The majority spoke of the tainted evidence as cumulative of only "largely uncontroverted" evidence. Id. at 224, 231. An examination of the record reveals, however, that the defense did not challenge the accuracy of either confession; the defense rested its case on the insufficiency of evidence to establish that the goods the defendants had conspired to transport were worth more than $\$ 5000$, as the federal statute under which they were charged required. Record at 152, 154. Moreover, the Court in Brown rested its decision on overwhelming evidence as well as cumulative evidence.

91470 F.2d 64 (7th Cir.), cert. denied, 409 U.S. 1011 (1972).

92 Id. at 65 .

${ }^{93}$ The court implied that Bruton might not be violated when the complaining defendant's uncontested confession was extremely similar to the complained of admission. But $c f$. id. at 65; text accompanying notes 104-06 infra. It then said that "if error was committed it was harmless" in this case. $470 \mathrm{~F} .2 \mathrm{~d}$ at 66.

${ }^{94} 405$ U.S. 427 (1972). 
confession, and that he confessed only after the police engaged in coercive tactics. (The Florida Supreme Court had held the improper police tactics sufficiently remote from the statements to dissipate the taint.) The trial judge had initially found Schneble's confession voluntary but then had left the issue to the jury, together with the other issues in the case, instructing them to disregard Scheble's confession if they found it involuntary.

Although Schneble's confession was thus disputed, the Supreme Court, per Rehnquist, J., considered it as part of the untainted evidence of which the codefendant's statement was merely corroborative. ${ }^{95}$ The basis of this approach was the Court's own finding that the facts related in Schneble's confession were accurate because they were "minutely detailed," 96 "internally consistent, were corroborated by other objective evidence, and were not contradicted by any other evidence in the case. They were consistently reiterated by petitioner on several occasions after his first exposition of them."97

The Supreme Court had limited its grant of certiorari so as not to review the voluntariness issue as such. It found, however, that the jury must have found Schneble's confession voluntary, because if it had not, there would not have been sufficient evidence to convict. ${ }^{98}$ By thus saying that the jury necessarily found Schneble's confession entirely reliable, the Supreme Court raised the confession to the status of indisputable evidence, although it was in fact vigorously disputed. The Court went on to say:

Charged as they were by the judge that they must be "satisfied beyond a reasonable doubt" and "to a moral certainty" of Schneble's guilt before they could convict him, the jurors could on no rational hypothesis have found Schneble guilty without reliance on his confession. Judicious application of the harmless-error rule does not require that we indulge assumptions of irrational jury behavior when a perfectly rational explanation for the jury's verdict, completely consistent with the judge's instructions, stares us in the face. See Rogers $v$. Missouri Pacific R. Co., 352 U.S. 500, 504-505 (1957).

Having concluded that petitioner's confession was considered by the jury, we must determine on the basis

\footnotetext{
${ }^{95} I d$. at 431 .

96405 U.S. at 430.

${ }^{97} \mathrm{Id}$. at 431.

${ }^{98}$ But cf. Jackson v. Denno, 378 U.S. 368 (1964).
} 
of "our own reading of the record and on what seems to us to have been the probable impact ... on the minds of an average jury," Harrington v. California, supra, at 254, whether [the codefendant's] . . . admissions were sufficiently prejudicial to petitioner as to require reversal.

... [U]nless there is a reasonable possibility that the improperly admitted evidence contributed to the conviction, reversal is not required. See Chapman $v$. California, 386 U.S. 18, 24 (1967). In this case, we conclude that the "minds of an average jury" would not have found the State's case significantly less persuasive had the testimony as to Snell's admissions been excluded. The admission into evidence of these statements, therefore, was at most harmless error.

\section{Affirmed..$^{99}$}

Justice Marshall's dissent, by contrast, expressed his views that there was "clearly enough evidence to support either a finding of voluntariness or one of coercion" in regard to Schneble's confession; that it was "possible that the jury may have found the statements to be involuntary and still relied on them;" and that, unlike the majority, he could imagine jury findings rejecting some or all of Schneble's statements or other evidence and relying primarily on the codefendant's statement to support the conviction. ${ }^{100}$ The outcome of the case thus turns on the different conclusions concerning the reliability of the "untainted" evidence by the majority and the dissent. ${ }^{101}$

99405 U.S. at 431-32.

${ }^{100} \mathrm{Id}$. at $436-37$.

${ }^{101} \mathrm{It}$, of course, is error under the overwhelming evidence test as well to allow evidence the jury may have disbelieved to sustain a finding of overwhelmingness. Yet In re Cline, 255 Cal. App. 2d 115, 63 Cal. Rptr. 233 (1967), cert. denied, 392 U.S. 938 (1968), makes the same error in an overwhelming evidence context. In that case police officers illegally obtained an extrajudicial admission from the accused, which was introduced against him at trial. The California Court of Appeal thought there was a reasonable possibility that the accused's decision to testify in his own behalf derived from the illegal testimony and that his own testimony was extremely damaging to his case. As the court put it:

Seated on the witness chair, he spun a fanciful exculpatory story, arousing the jury's opinion he was almost certainly a liar and exposing himself to impeachment by evidence of four prior felony convictions. If his courtroom position had any hope of rescue, his decision to take the stand would have demolished it.

Id. at 124, 63 Cal. Rptr. at 239. The Court of Appeal thus considered Cline's in-court testimony as well as his extrajudicial statement as part of the tainted evidence and deemed it highly incriminating. Nonetheless the court held the error harmless:

Viewed in relationship to the massive, immovable, independent evidence of 
People v. Coffey ${ }^{102}$ provides another example of how an ostensibly prejudicial error can be excused by an appellate court's independent evaluation of the probative value of untainted evidence. Coffey was convicted of assault with a deadly weapon upon several police officers. He denied that he had aimed gunshots at any person or had intended to harm or to kill anyone. A prior criminal conviction, which may have been obtained unconstitutionally because of denial of counsel at trial, was used to impeach Coffey's credibility. The California Supreme Court held that, if the prior conviction was unconstitutional, its use to impeach was federal constitutional error. It held, moreover, that the error was harmful with respect to counts involving two of the police officers because no direct evidence showed that the defendant had directed his fire at them or intended to harm them; the prior conviction may therefore have materially influenced the jury in finding against the defendant on those points. With respect to counts involving two other policemen, however, the court said the error could not reasonably have harmed the defendant because

there was precise and unequivocal testimony by the officers involved that defendant, when requested to drop his weapon and surrender, turned and fired directly at them. Further, there was physical evidence to the effect that bullets fired at this time by defendant struck very near the officers. Defendant's story, of course, was that

guilt, his decision [to testify] was harmless .... The guilt of the accused was unassailably demonstrated by incontestable proof, independently of the errortinged evidence.

... Neither his inadmissible statement nor an adverse jury reaction to his courtroom testimony could damage a case lost beyond repair.

Id. at 124-25, 63 Cal. Rptr. at 240.

The problem with this reasoning, even under the overwhelming evidence test, is that the untainted evidence was indisputable/uncontestable/overwhelming only on the assumption that it was believed by the jury despite the accused's contradictions of it, which the court adjudged to be "fanciful." Its characterization of the untainted evidence as overwhelming thus depended on its assumption that the jury found the policemen perfectly credible and Cline entirely incredible. Through this assumption the court attributes to the triers of fact conclusions that they did not necessarily draw. Moreover, the accused's inadmissible extrajudicial statement had particular bearing on one element of the crime-the element requiring that the accused be aware of the officer's official identity. With respect to this point, Cline can be seen as a cumulative evidence case rather than an overwhelming evidence case, for there was untainted evidence that the accused knew that the persons he was assaulting were officers: the officers testified that they had announced their identities before firing a warning shot. It is not clear, however, that the jury found this element of the crime proved because it accepted the officers' testimony or because instead, or in addition, it relied on the illegal evidence.

10267 Cal. 2d 204, 430 P.2d 15, 60 Cal. Rptr. 457 (1967). 
the officers opened fire upon him when he was trying to surrender, and that he returned their fire and ran back into the house. However, there was also evidence to the effect that the officers were under explicit instructions not to fire upon defendant unless fired upon. We also consider the fact that the jury was properly instructed that the presumption of truth-telling on the part of a witness may be repelled by the interest of that witness in the case. ${ }^{103}$

If the cumulative evidence test is generally less vulnerable than the overwhelming evidence test to a charge of fostering usurpation of jury functions, its superiority disappears when the test is applied as in Schneble and Coffey. It may be, and probably is, objectionable for an appellate court ever to hold that a jury would necessarily find against the defendant on evidence essentially different from the evidence actually before the jury that has already convicted. But these cases go further and recreate the thinking processes of the jury to accord with what the appellate court believes is the most rational way to view the evidence. This difficulty inheres in a rule that allows an appellate court to hold constitutional error harmless whenever duplicative evidence itself must be believed beyond a reasonable doubt (in other words, is indisputable); the appellate court usurps the jury's function when it rules that the jury could not reasonably have believed the tainted evidence and disbelieved the untainted evidence.

The theory behind a rule that would require only that the untainted evidence have superior probative force does, however, have its adherents. Michael R. Fruehwald offers an explanation of harmless error that is relevant in this context:

[F]rom the total record it is assumed that the jury rationally relies upon the most direct and persuasive evidence to decide an issue and retreats to more remote and less credible evidence only if it is needed to meet strong evidence on the other side. If the evidence against the defendant is overwhelming, the jury needs only the best evidence to resolve its doubt. The weaker the character and quality of the tainted evidence rela-

${ }^{103}$ Id. at 223-24, 430 P.2d at 28, 60 Cal. Rptr. at 470 (footnote omitted). The same error is made in Olivas v. Arizona ex rel. Eyman, 447 F.2d 974 (1971), which held a Bruton error harmless because "[i]t did no more than restate what had already been testified to by the eye witness." Id. at 976 . 
tive to other evidence on the issue, the more probable the jury was able to and did ignore it in reaching the verdict. Under this model the issue is not whether there is overwhelming evidence to convict, but rather whether there is overwhelming evidence of a quality better than that erroneously admitted. ${ }^{104}$

The appellate court is viewed here as the final arbiter of credibility; the "pecking order" of evidence is determined according to the court's perception of what constitutes "the most direct and persuasive evidence." The encroachment on the jury's function is even greater here than under the overwhelming evidence test because the court is substituting its judgment (in theory, beyond a reasonable doubt) to say not only what conclusion the jury would have reached but also which evidence it would have believed and disbelieved in reaching that conclusion. In fact, the less probative evidence may have played a role in the conviction if the jury disbelieved the more probative evidence.

Even if one accepts an appellate court's ability accurately (and constitutionally) to determine that the jury would not, beyond a reasonable doubt, have believed the evidence the appellate court considers less probative unless it also believed the evidence the appellate court considers more probative, the possibility exists that it was the effect of the two pieces of evidence together that persuaded the jury to believe both. Assume, for example, a case involving the admission of two confessions by the same defendant-the second violative of Miranda, the first properly admitted. The issue is whether the unconstitutionally admitted confession was harmless. The confessions are much alike, the first (and proper) one being somewhat more detailed. The defense questioned the voluntariness (and consequent reliability) of both confessions, presenting to the jury a more convincing case with respect to the second, improper confession than the first. The proper evidence therefore is clearly superior to the improper evidence in probative value, and the confessions, in terms of degree of similarity, can be seen as cumulative. But even if it is reasonable to find (beyond a reasonable doubt) that the jury could not have credited the tainted confession without crediting the untainted confession, the possibility clearly ex-

${ }^{104}$ Note, Miranda Warnings and the Harmless Error Doctrine: Comments on the Indiana Approach, 47 IND. L. J. 331, 333-34 n.16 (1971). Although Fruehwald wrote about the overwhelming evidence test, his point is relevant in connection with cumulative evidence as well. 
ists that the jury would have disbelieved the proper confession had it been the only one in the case and that the improper confession tipped the balance against the defendant. It is possible, then, that improper evidence will add together with proper evidence to have an incriminating impact if only superior probative value is demanded of the untainted evidence. Accordingly, the cumulative evidence test should require that the untainted evidence be indisputable, in addition to imposing requirements of similarity between the tainted and untainted evidence.

\section{The Problem of Fruits}

Another possible interrelationship between the tainted and the untainted evidence that the cumulative evidence test should recognize is that the untainted evidence may derive, in whole or in part, from the tainted evidence. This interrelationship may exist whether or not the untainted evidence is disputable. Whenever it does exist, the tainted evidence may have played a role in the conviction. In fact, if "untainted" evidence does derive from the tainted evidence, both should be considered tainted; the problem lies basically in accurately separating the tainted from the untainted evidence in the first instance. It is important, both to the cumulative evidence test and to the overwhelming evidence test, that "untainted" evidence not derive from tainted evidence. Otherwise the constitutional error is allowed to play a part in the conviction and still be called harmless. Yet many cases ignore this seemingly elementary point. In Fahy $v$. Connecticut, ${ }^{105}$ for example, it seems quite possible that the "untainted" evidence, on which the state court relied to uphold the conviction, in fact derived from the illegal search and seizure, and the Supreme Court so found. ${ }^{106}$ In Motes $v$. United States $^{107}$ as well, the petitioner's in-court confession probably derived from the erroneously admitted accusation of him. The transcript of Taylor's earlier accusations, as part of the

105375 U.S. 85 (1963).

${ }^{106}$ The Court said that the illegal evidence was corroborative of police testimony (that otherwise might not have been believed), that it was the basis of opinion testimony that the paint and brush matched the markings on the synagogue, and that it might have induced Fahy's confession. Id. at 86-87. If authority is needed for the proposition that evidence should not be deemed untainted if it derives from the tainted evidence, Fahy provides it, for in assessing the effect of the tainted evidence, the Court examines its effect "upon the other evidence adduced at trial and upon the conduct of the defense." Id. at 87.

${ }^{107} 178$ U.S. $458(1900)$. 
prosecution's case, probably preceded Motes' testimony, which was placed in evidence by the defense, ${ }^{108}$ and quite possibly Motes would have had no reason to testify except for the erroneously admitted statements; the Court's opinion does not disclose other evidence of guilt of any of the accused. ${ }^{109}$ (In Harrington, a derivative relationship seems less likely because the defendant's statement was made before trial, and the Bruton violation occurred at trial. ${ }^{110}$ )

\section{Summary}

Three requisite elements of the cumulative evidence test have been suggested: (1) There should be substantial similiarity, in type of evidence and incriminating factual details, between the tainted evidence and the untainted evidence of which it is "cumulative." (2) The untainted evidence should be indisputable, either because the facts are in some way affirmatively accepted by the defendant or for other reasons. (3) Care should be taken that the "untainted" evidence in no way derives from the tainted evidence.

\section{Evaluation of the Cumulative Evidence Test Thus Defined}

People v. Jacobson, ${ }^{111}$ a California Supreme Court case, would suggest that the proposed limitations on the cumulative evidence test make it too narrow. In that case, the court found roughly ten separate confessions by the defendant that he had murdered his baby daughter. The majority found voluntary and spontaneous the first eight confessions, six of which were made to people other than the police. The last two confessions, however, were constitutionally impermissible, having been extracted in violation of Escobedo $v$. Illinois. ${ }^{112}$ According to the majority, all the confes-

${ }^{108}$ The Court also says that the erroneously introduced evidence was the first evidence of conspiracy introduced in the case. Id. at 471. Motes' evidence also attested to a conspiracy.

${ }^{109}$ Similarly, in Vasquez v. State, 254 Ind. 472, 260 N.E.2d 779 (1970), cert. denied, 401 U.S. 1012 (1971), and Greer v. State, 252 Ind. 20, 245 N.E.2d 158 (1969), discussed in note 86 supra, in which the defendants admitted at trial the facts introduced against them in statements violative of Miranda, the "untainted" evidence may have derived from the constitutional error.

${ }^{110}$ Even in this situation, however, a defendant's failure to dispute his own statement at trial could conceivably result from the Bruton violation.

${ }_{111} 63$ Cal. 2d 319, 405 P.2d 555, 46 Cal. Rptr. 515, cert. denied, 384 U.S. 1015 (1965).

${ }_{112} 378$ U.S. 478 (1964). Quaere why the prosecution should have introduced the clearly questionable confessions in such an apparently airtight case. $C f$. note 56 supra. 
sions were identical in incriminating content. Moreover, no one confession was unduly emphasized at the guilt phase of the trial. The majority therefore held the two improper confessions "merely cumulative" of the prior admissible statements, noting that the sequence of the confessions was such that the proper ones could not have derived from the improper ones. ${ }^{113}$

If one accepts the majority's version of the facts, ${ }^{114}$ this holding appears sensible. Yet the "undisputed/indisputable" criterion is not met. For the defendant did contradict the series of confessions when he took the stand, saying that he suffered a period of "blackness" after which he discovered his daughter dead.115 If we persist with our three criteria for the cumulative evidence test, therefore, it seems impossible to hold the last two confessions harmless under that test, even though the usual reasons for questioning a court's finding of cumulativeness when the untainted evidence is in dispute do not seem to apply. They do not apply because the similarity of the evidence is so great (according to the majority's version of the facts) and because the number of confessions is so great that it is difficult to believe that the tainted confessions had an independent impact. Both factors are crucial to creating a situation in which we would not wish to apply the proposed cumulative evidence limitations; and it is also crucial that the tainted confessions were the last in the series. If the case were less extraordinary, in the sense that two or three confessions were involved rather than ten, the cumulative evidence test should not apply, because of the danger that the confessions were accepted over the trial testimony only because they

${ }^{113} 63$ Cal. 2d at 330-31, 405 P.2d at 563, 46 Cal. Rptr. at 523. Prior to Jacobson, the use of unconstitutional confessions was subject to automatic reversal in California courts. People v. Dorado, 62 Cal. App. 2d 350, 398 P.2d 361, 42 Cal. Rptr. 169, cert. denied, 381 U.S. 937 (1965). Perhaps when cumulativeness is the harmless error test, however, a different category of automatically reversible error is mandated than when another test of harmlessness is used. (In note 56 \& text accompanying notes 54-60 supra, we saw, by analogy, differences in the automatic reversal problem depending upon whether the first approach or an overwhelming evidence test was used.) Allowing a harmless error finding when the erroneously admitted confession is cumulative with a confession of the same defendant certainly does not seem inconsistent with refusing to allow it simply because the weight of other evidence in the case is overwhelming.

${ }^{114}$ The dissenter disagreed with the majority not only concerning whether an illegally obtained confession could ever be harmless but also concerning whether the majority was correct in deeming the first few statements made to police officers to be wholly voluntary.

${ }^{115} 63 \mathrm{Cal}$. 2d at 333, $405 \mathrm{P} .2 \mathrm{~d}$ at 564, $46 \mathrm{Cal}$. Rptr. at 524. To say that the untainted evidence was nonetheless "indisputable" because the case against the defendant was so strong would emasculate this requirement of the cumulative evidence test. Therefore, the evidence must be considered disputable because it was in fact disputed. 
reinforced each other. Moreover, if the tainted confession is at the beginning of a series of confessions, instead of at the end, then, no matter how long the series, the later confessions may derive from the earlier improper one. In addition, the more the tainted confessions differ from the untainted ones, the more likely it is that they had a different impact on the jury, and thus could reasonably have been determinative in causing rejection of the trial testimony.

The contradiction between the result that seems sensible on the facts of Jacobson and the proposed limitations on the cumulative evidence test should not result in a rejection of the limitations, for the need for them exists in the vast majority of cases. Tailoring the rule instead to accommodate the rare situation found in Jacobson might lead in the general run of cases to the abuses found in Schneble and Coffey. The danger of making an explicit exception to cover the Jacobson situation is that its terms would be interpreted to include cases with facts less compelling than Jacobson, and hence the exception would come to swallow the rule, or at least part of it.

Whichever way one comes out on this admittedly debatable issue, it is important to enunciate the requirements of the cumulative evidence test-and any exceptions to those requirements that might exist-in order to give content to the test. This is vital if the test is to be retained at all, either in conjunction with both of the other tests, or merely with the first of them. ${ }^{116}$

If the strict requirements suggested above are imposed, the cumulative evidence test is a sensible means for determining the harmlessness of error. Under it, appellate court encroachment upon the province of the jury is far less substantial than under the overwhelming evidence test. ${ }^{117}$ Findings of harmlessness also are more reviewable under this test than under the overwhelming evidence test: an appellate court need only examine the tainted evidence and the particular untainted evidence with which the error is allegedly cumulative-evidence that those urging harmlessness can be expected to point out. It seems

${ }^{116}$ Even if the overwhelming evidence test is retained as well, there are some cases in which the cumulative evidence test would allow a finding of harmlessness while other tests would not. The argument for retaining the test in these cases weakens, however, in view of the small number of cases in which cumulativeness, properly applied, would allow a finding of harmlessness while neither of the other tests would. Affirmance in that narrow category of cases might not be worth the costs of retaining the test, with all of its pitfalls and litigable issues.

${ }^{117}$ See text accompanying note 82 supra. 
proper not to overturn a conviction and require a new trial in cases in which this strict definition of cumulativeness is met, for the constitutional error appears truly to have played no role in procuring the conviction.

\section{Conclusion}

It is unclear whether or not the Supreme Court intends that the cumulative evidence test be viewed as a distinct means of assessing harmlessness. As noted earlier, the Court in Harrington does not state clearly whether the similarity between the untainted and the tainted evidence is important to its holding of harmlessness or whether the overwhelming quality of the untainted evidence is alone responsible for the result. ${ }^{118}$ Lower courts and commentators have accordingly differed in their readings of Harrington. ${ }^{119}$ And Harrington is the Supreme Court case that to date most clearly enunciates a cumulative evidence test. In this respect, Harrington provides a good example both of the confusion regarding harmless error generally and of the Court's failure to differentiate between various processes of determining harmlessness even though those processes can lead to different results. The dissent in Harrington, authored by $\mathrm{Mr}$. Justice Brennan, has the same difficulty as the majority opinion. It begins by criticizing the majority for confusing quite different approaches. Viewing the majority's opinion as endorsing the overwhelming evidence test, it contains the most coherent exegesis to be found in Supreme Court opinions of the difference between the first approach and the overwhelming evidence

${ }^{118}$ Indeed, the last four sentences quoted in text accompanying note 72 supra, may state that cumulativeness alone is not sufficient to render evidence harmless if that evidence would be clearly harmful under the first approach to harmless error and that only overwhelming untainted evidence can render such errors harmless.

Other cases, in addition to Harrington, confuse the cumulativeness and the overwhelming evidence tests, and treat them as fungible. E.g., Brown v. United States, 411 U.S. 223 (1973); Schneble v. Florida, 405 U.S. 427 (1972). See also Milton v. Wainwright, 407 U.S. 371 (1972), an overwhelming evidence case that could have been analyzed as a cumulative evidence case.

${ }^{119}$ Some support the cumulative evidence reading. State v. Martin, 107 Ariz. 444, 448-49, 489 P.2d 254, 258-59 (1971); In re Lara, I Cal. 3d 486, 489-90, 462 P.2d 380, 382, 82 Cal. Rptr. 628, 630-31 (1969); Note, The Admission of a Codefendant's Confession After Bruton v. United States: The Questions and a Proposal for Their Resolution, 1970 DUKE L.J. 329, 344-50. The majority of cases considering Harrington, however, treat it as an overwhelming evidence case. E.g., Hoover v. Beto, 467 F.2d 516, 537 (5th Cir.), cert. denied, 409 U.S. 1086 (1972); United States v. Young, 422 F.2d 302, 308 (8th Cir.), cert. denied, 398 U.S. 914 (1970). See also Note, Application of the Harmless Error Doctrine: Comments on the Indiana Approach, 69 Mich. L. REv. 941, 943-44 (1971); 83 HaRv. L. REv. 814, 819-20 (1970). 
test, which it claims Chapman repudiated. ${ }^{120}$ But after so carefully differentiating between the overwhelming evidence approach and the first approach that does not allow "plainly relevant evidence which possibly influenced the jury" to be deemed harmless and that insists "that a conviction cannot constitutionally be based to any extent on constitutional error," the dissent then asserts that "[ $t]$ he focus of appellate inquiry should be on the character and quality of the tainted evidence as it relates to the untainted evidence and not just on the amount of untainted evidence."121

Here, Justice Brennan drifts away from the pure first approach he advocates at the beginning of his opinion and elides the various tests. The ensuing portions of the opinion suggest that Justice Brennan will not look merely to whether the unconstitutional evidence was of a type likely to influence the jury, but also will discount the evidence if its effect is duplicated by other untainted evidence in the case. In a way that suggests the cumulative evidence test, he examines the difference between the untainted evidence against Harrington and the tainted evidence, which he believes is fuller and more probative. ${ }^{122}$ Yet his discussion has not recognized the cumulative evidence test as a distinct means of assessing harmlessness. Like the majority,

120 In Chapman, we . . . emphasized that "[a]n error in admitting plainly relevant evidence which possibly influenced the jury adversely to a litigant cannot . . . be conceived of as harmless." . . [ [W] left no doubt that for an error to be "harmless" it must have made no contribution to a criminal conviction.

Chapman, then, meant no compromise with the proposition that a conviction cannot constitutionally be based to any extent on constitutional error. The Court today by shifting the inquiry from whether the constitutional error contributed to the conviction to whether the untainted evidence provided 'overwhelming' support for the conviction puts aside the firm resolve of Chapman and makes that compromise. ...

The Court holds that constitutional error in the trial of a criminal offense may be held harmless if there is 'overwhelming' untainted evidence to support the conviction. The approach, however, was expressly rejected in Chapman,... . and with good reason. For where the inquiry concerns the extent of accumulation of untainted evidence rather than the impact of tainted evidence on the jury's decision, convictions resulting from constitutional error may be insulated from attack. By its nature, the issue of substantiality of evidence admits of only the most limited kind of appellate review. Thus, the Court's rule will often effectively leave the vindication of constitutional rights solely in the hands of trial judges. If, instead, the task of appellate courts is to appraise the impact of tainted evidence on a jury's decision, as Chapman required, these courts will be better able to protect against deprivations of constitutional rights of criminal defendants.

395 U.S. at 255-56 (citations omitted) (emphasis in original).

${ }^{121} I d$. at 256 (emphasis supplied).

${ }^{122} I d$. at 256-57. 
therefore, Justice Brennan does not differentiate clearly between the separate ways of assessing harmlessness.

Both opinions in Harrington therefore illustrate the confusion of harmless error tests that characterizes Supreme Court opinions generally. ${ }^{123}$ Nor do the three different tests we have examined exhaust the possibilities. Another test alluded to in one case is a compare-the-weight-of-the-evidence approach, ${ }^{124}$ an approach that has dramatic potential for appellate displacement of jury deliberations. And other tests are possible as well.

This Article supports retention of the first approach-an examination of the persuasiveness of the erroneously admitted evidence-accompanied only by a narrow cumulative evidence test. In other words, constitutional error should be declared harmless only when the error itself was either irrelevant or trivial, or when other independent, substantially similar evidence indisputably proved the propositions to which the tainted evidence was relevant. The most obvious criticism of this position is that it is too narrow because it prevents holdings of harmlessness in certain appropriate situations. Two examples discussed above are the Jacobson case ${ }^{125}$ and the hypothetical in which the prosecution introduces into evidence photographs of a robbery in commission but also introduces illegally obtained evidence. In order for harmless error rulings to be possible in such situations (and in others in which "common sense" might tell us that the

${ }^{123}$ The difference between the majority's and the dissent's readings of the Harrington record, see note 87 supra, is not unusual in harmless error cases, for the majority and dissenting opinions often reflect important differences in factual analyses. See, e.g., Milton v. Wainwright, 407 U.S. 371, 383-84 (1972); Schneble v. Florida, 405 U.S. 427, 434-37 (1972); Bumper v. North Carolina, 391 U.S. 543, 550 n.16 (1968); People v. Jacobson, 63 Cal. 2d 319, 336-42, 405 P.2d 555, 566-70, 46 Cal. Rptr. 515, 526-30 (1965), cert. denied, 384 U.S. 1015 (1966). (When only one opinion is written, questionable factual analysis may not be apparent.) Even if consensus were reached as to the proper harmless error test, therefore, it is likely that questionable factual analysis would continue to be a source of arbitrary harmless error results. The first approach-focusing on the error alone to see if it is of a type likely to be influential with the jury-probably lends itself less to differing factual analyses than does either of the others.

${ }^{124}$ See Schneble v. Florida, 405 U.S. 427, 430 (1972). The Court does not distinguish between such an approach and the overwhelming evidence test, stating that "[i]n some cases the properly admitted evidence of guilt is so overwhelming and the prejudicial effect of the codefendant's admission is so insignificant by comparison, that it is clear beyond a reasonable doubt that the improper use of the admission was harmless error." (emphasis supplied). See also In re Cline, 255 Cal. App. 2d 115, 63 Cal. Rptr. 233 (1967), cert. denied, 392 U.S. 938 (1968), discussed in note 101 supra; text accompanying note 121 supra.

${ }^{125}$ Notes 111-17 supra \& accompanying text. 
result of the case would not have been determinatively affected by avoidance of the constitutional error), one might prefer the current amalgam of half-articulated tests and doctrines to the formulation of any precise harmless error rules. For it is difficult to design rules that would include all those cases in which findings of harmlessness would seem appropriate, while excluding all others. ${ }^{126}$ The difficulty with that position is that it essentially argues against the rule of law in this area. It permits highly arbitrary results and does not allow the case law to develop to correct shortcomings that are perceived in the rules, because it does not force elucidation and discussion of the real variables that go into a particular decision whether to hold error harmless. I would prefer some underinclusiveness in the harmless error doctrine, especially because the prosecution often could avoid reversal by simply not committing the constitutional error in the first instance. ${ }^{127}$ Indeed, in my mind, the comparative merits of the various alternatives discussed-the principal issue being whether or not to retain an overwhelming evidence test-are less clear than the desirability of enunciating what test or tests are to govern and the requirements of each. Only when that is done will it be possible for an appellate court operating in good faith to apply the harmless error test or tests in a principled fashion. And open discussion of the actual reasons for harmless error decisions should allow categories to evolve that more clearly and correctly dispose of harmless error problems.

${ }^{126}$ Another possible fear is that the unavailability of harmless error rulings will lead courts to undermine the constitutional rules themselves when faced with convictions they want to preserve. It is not difficult to document the interdependence of findings of error and findings of harmlessness. Indeed, in some cases the court blurs its findings, not informing us whether no error occurred or whether instead there was constitutional error but it was harmless. E.g., Schneble v. Florida, 405 U.S. 427 (1972); United States v. Spinks, 470 F.2d 64 (7th Cir.), cert. denied, 409 U.S. 1011 (1972).

${ }^{127}$ This, of course, will not be true in those cases in which constitutional error appears only in light of a subsequent court ruling that is applied retroactively. See generally note 56 supra. 